\title{
Investigation of the effects of financial regulation and supervision on bank stability: The application of CAMELS-DEA to quantile regressions
}

\author{
by \\ Ali Shaddady ${ }^{\mathrm{a}}$ and Tomoe Moore ${ }^{\mathrm{b}^{*}}$ \\ Department of Finance, King Abdulaziz University, \\ Jeddah, Saudi Arabia, P.O. Box : 80200. Zip Code : 21589. \\ Tel: +966126400000 \\ ${ }^{\mathrm{a} b}$ Department of Economics and Finance, Brunel University London, \\ Uxbridge, Middlesex, UB8 3PH, UK. \\ Tel: + 44 1895274000, Fax: +44 1895269770 \\ amshaddady@kau.edu.sa \\ tomoe.moore@brunel.ac.uk \\ *Corresponding author
}




\title{
Investigation of the effects of financial regulation and supervision on bank stability: The application of CAMELS-DEA to quantile regressions ${ }^{\dagger}$
}

\begin{abstract}
We rigorously investigate the multifaceted effects of financial regulation and supervision on bank stability using panel data for 2210 banks across 47 European countries over the period 2000-2016. The CAMELS rating system is applied to quantile regressions. We find that greater capital regulation is positively associated with bank stability, whilst tighter restrictions, deposit insurance and excess of supervision appear to exert an adverse effect on bank stability. These effects are more pronounced among banks at a higher level of stability. It also appears that commercial banks, smaller banks and banks in emerging countries are relatively sensitive to regulatory shocks.
\end{abstract}

Keywords: Bank stability; Financial regulation; Bank supervision; CAMELS; Quantile approach

JEL classifications: G21; G28; G24

\footnotetext{
${ }^{\dagger}$ We thank an anonymous referee of the journal for constructive suggestions.
} 


\section{Introduction}

The controversy about the relationship between regulation and stability has created practical questions, whether strict regulation besides supervision are appropriate for all financial markets and institutions, and which type of regulation can be pursued. For example, Barth et al. (2004), Pasiouras et al. (2006), Pasiouras et al. (2009), Barakat and Hussainey (2013) and Delis (2015) highlight the need for tighter financial regulation to promote financial stability and the importance of building stable buffers to meet any financial distress. On the other hand, some researchers have argued that stricter regulation may destabilise the financial system. Hakenes and Schnabel (2011) stated that onerous regulation may be a hindrance to the ability of banks to provide financial resources for economic sectors. Such regulation may also have an adverse effect on bank competition leading to higher loan rates and to potentially a higher probability of loan defaults. Note that Demirgüç-Kunt and Detragiache (2011) did not find any significant positive impact of regulation and supervision on financial stability.

In this paper, we rigorously investigate the multifaceted effects of regulation together with supervision on bank stability using a large data set of an unbalanced panel of 2210 banks across 47 European countries over the period 2000-2016. Our study distinguishes itself from existing studies in the following manner: Whilst most financial stability research has suffered from inadequate measurement of stability scores (Wanke et al., 2016), we adopt a CAMELS-DEA rating system as a stability indicator. CAMELS is an acronym for categories of financial variables encountered in the financial literature, referring to capital adequacy $(\mathrm{C})$, asset quality (A), management efficiency (M), earnings (E), liquidity (L) and sensitivity to market risk (S), and DEA is data envelopment analysis. Our study combines this system with a quantile regression technique to take account of varying levels of stability across banks. We also consider the multifaceted influences of regulation and supervision with variations in business models, bank size and economic development.

Several studies have investigated the concept of financial stability, however, debate regarding the precise definition of financial stability has been ongoing. Crockett (1997) considered stability in both institutions and markets, whereby stability in financial institutions may refer to the absence of stress, and stability in the financial market may refer to the absence of volatile price movements. Issing (2003) defines financial stability as a system which can guarantee an efficient allocation of savings in order to enhance investment 
opportunities. In a similar vein, the European Central Bank (2005) interprets financial stability as a system which can provide continued support for an economy. Borio (2003) expounded financial stability based on two main paradigms of the micro-prudential and macro-prudential. See also Garry and Schinasi (2004). The complexity of identifying financial stability leads to different ways of quantifying such stability for an empirical work. The widely used indicator at the micro-level is the Z-score (Altman 1968, Altman et al.1977, Boyd and Graham 1986, Hannan and Hanweck 1988 and Uhde and Heimeshoff 2009), which reflects the probability of default in the banking system. However, this indicator suffers from several limitations. The Z-score is based purely on an accounting and auditing framework, and, hence, it does not take into account other sources of risk such as the sensitivity of market risk or management risk (Čihák et al. 2012 and Creel et al. 2015). Iannotta (2007) used loan loss provision (LLP) to total loans as a proxy for banking credit risk. At a macro-level, Loayza and Ranciere (2006) utilised the standard deviation of private credit to GDP so as to capture financial fragility. In addition, Hollo et al. (2012) developed a financial stability measurement through a composite indicator of systemic stress (CISS).

Männasoo and Mayes (2009) propose CAMELS indicators that appear to have a significant ability to detect any financial distress, hence the related financial variables of the CAMELS acronym have been adopted in several studies. See, for example, Cole and Gunther (1995), DeYoung (1998), Kumar and Ravi (2007) and Poghosyan and Čihák (2009). Avkiran and Cai (2012) presented empirical evidence which emulated the CAMELS rating system in Australian bank holding companies through the use of a non-parametric technique, DEA. Avkiran and Cai emphasised that DEA can be utilised as a forward-looking substitute method that assists in detecting financial distress in the near future. More recently, Wanke et al. (2015) and Wanke et al. (2016) also examined the CAMELS rating system in Brazilian and Malaysian banks by using DEA, and proved that the CAMELS with DEA is an appropriate method to uncover any financial distress.

We apply the CAMELS-DEA rating system to the quantile regression (QR) method ${ }^{1}$. Then means that the dependent variable, bank stability, estimated by the CAMELS-DEA is distinguished by its variations in the level of stability. The approach is appropriate for discovering whether bank stability is related to our explanatory indicators at different points of bank stability distribution. This has a number of advantages. The traditional inference

\footnotetext{
${ }^{1}$ QR is developed by Koenker and Bassett (1978).
} 
methods such as ordinary least squares (OLS) or least absolute deviations (LAD) are developed to describe average behaviour of a sample (Lee and Li 2012). It is argued that these methods exhibit rather poor descriptions, especially with the presence of heterogeneity in the sample. There is a two-step estimation procedure where the sample is partitioned based on a particular factor and then the conventional econometrics estimation is applied. This enables us to conduct a comparative analysis between the partitioned segments. The drawback of this method is, however, the potentially invalid empirical results due to sample selection bias. The QR circumvents the limitation of the two-step analysis. Moreover, the QR approach allows us to explore a range of conditional quantile functions, thereby exploring various forms of conditional heterogeneity (Lee and Li 2012). It is further argued that since sample segmentation and non-uniform relations between the dependent variable and the explanatory variables are simultaneously determined, the $\mathrm{QR}$ is able to deal with the potential limitations in prior studies that assume segmentation of the sample is exogenous (Lee and $\mathrm{Li}$ 2012). The QR is employed in various finance studies. Among others, Engle and Manganelli (2004) for the study of VaR, Chuang et al. (2009) for the return-volume relation in the stock market and Cappiello et al. (2010) for the impact of the Euro on stock markets. To the best of our knowledge, this paper is the first attempt to apply the QR models to testing the effect of financial regulation and supervision on bank stability. Note that this proved to be a plausible approach, since different results are found at varying levels of stability in banks.

Many studies have examined the influence of banks' business models on financial stability. For example, Demirgüç-Kunt and Huizinga (2010) find that banks with a high degree of diversified activities may produce more risks. Altunbas et al. (2011) stated that banks' business models that shape an aggressive credit growth and large balance sheets may face distress, conversely, any bank business model that is based on high deposits coupled with significant diversification of assets is less likely to face financial distress. Likewise, Ayadi et al. (2012) argue that retail-oriented banks are more profitable and stable, compared with other types of financial institutions. See also Köhler (2015) and Mergaerts and Vander Vennet (2016). Mergaerts and Vander Vennet (2016) argue that heterogeneity among banks' business models may have different reactions to prudential regulation and methods of supervision.

The debate about the effect of bank size on financial stability has also gained much attention since it was evident that the crisis which originated in the large global banks, has 
spread the source of financial distress across many countries. The agency theory suggests that managers who run large banks can gain private benefits and obtain more compensation (Murphy 1985, Jensen 1986 and Gabaix and Landier 2008). With this perspective, it is possible to observe a negative relationship between bank size and financial stability. On the other hand, the stewardship theory presents a manager of a large bank as an inherently trustworthy person, and it is unlikely that such a person misappropriates a bank's resources (Davis et al. 1997). It is also argued that a large bank may reflect structural convenience, which may reinforce financial stability (Donaldson and Davis, 1991). These studies suggest that a sensitivity to regulatory shocks may vary according to a bank's size.

Demirg et al. (1998) investigated the determinants of banking distress across developing and emerging countries. They discovered that structural characteristics of the financial system together with a weak macroeconomic environment play key roles in increasing the probability of financial distress, especially in less-developed countries. Further, Čihák et al. (2012) and Wen and Yu (2013) find that there are significant variations in the relationship between financial depth and financial stability across high-income and low-income countries. It is argued that this is due to the different propagation of financial distress and the sources of stress. Weak early warning indicators in emerging economies are also said to influence the variations in the financial stability and the related determinants (Babecký et al., 2014).

The above arguments warrant investigation of the effects of regulation and supervision on bank stability in terms of banks' business models, size and the stage of economic development.

Our empirical work reveals the following main findings: In general, capital regulation has a positive influence on stability across all quantiles, i.e. all banks with various levels of stability. Such factors as concentrated markets and economic freedom also exert a favourable effect on bank stability. This is contrasted with the activity restrictions, deposit insurance, monitoring and supervision which have shown to adversely affect banks. These effects tend to be more pronounced in banks with a high level of stability. Note also that there appears to be a heterogenous effect across different business types of bank, bank size and economic development. In particular, commercial banks, smaller banks and also banks in emerging countries, albeit to a lesser degree, tend to be more sensitive to shocks in financial regulation and supervision. The empirical results found in this paper should serve 
to provide guidance for financial policymakers in designing and setting bank regulation and supervision.

Our study contributes to the literature in two ways. Firstly, our findings based on the QR method may reconcile the mixed results in the literature of the relation between regulation and stability. This may be due to the fact that the quantile approach considers the various distributions of the dependent variable that is not featured by the central distribution tendency. Secondly, we, in general, find well-determined coefficients, suggesting that a proper evaluation of the effect of regulation on bank stability may be the use of the multidimensional stability indicators by capturing banks' soundness with the combination of inputs and outputs indicators.

The rest of this paper proceeds as follows. Section 2 presents the relevant literature on the effects of regulation and supervision on bank stability. Other determinants are also discussed in this section. In Section 3, we describe the model specification, variables and data. The empirical results are presented in Section 4, and we conclude in Section 5.

\section{The relevant literature}

\subsection{Effects of bank regulations, supervision and internal monitoring on stability}

It is pointed out that capital-requirement regulation is one of the key instruments to enhance financial stability. Boot and Greenbaum (1992) and Besanko and Kanatas (1993), however, pointed out that a strict capital requirement decreases monitoring power. Moreover, Hakenes and Schnabel (2011) argue that a stringent capital requirement attenuates competition for loans, and thereby banks raise loan rates, leading to an increasing probability of default among borrowers. Nonetheless, an effective capital requirement is considered a useful instrument to absorb losses and to act as a buffer. Kim and Santomero (1988) showed the way in which a capital requirement can redress the bias towards risk. Further, strict capital requirements could prompt banks to reduce risky lending (Gambacorta and Mistrulli, 2004). Furlong and Keeley (1989) added that adequate capital requirements may maximise banks' values by enhancing investors' confidence, boosting banks' reputations and their franchise values (Repullo 2004). 
With respect to the influence of restrictions in non-traditional financial activities such as insurance, securities and property on financial stability, there are conflicting propositions. It is argued that tight restrictions may boost monitoring due to low-complexity banking activities, coupled with a reduction in informational asymmetries. However, relaxing restrictions enables banks to gain the benefits of diversifying their products. This may affect financial services and assist banks to provide more efficient services and enhance bank stability (Barth et al., 2004). See also Laeven and Levine (2007) and Barth et al. (2013b).

Deposit insurance is deemed to offer a safety buffer within the financial system. The deposit guarantee can boost depositors' confidence and reduce the role of government with regard to banks' obligations in the face of financial shocks (Anginer et al. 2014 and Constantinescu 2015). Santomero (1997) and Demirgüç-Kunt and Detragiache (2002), however, highlight that deposit insurance may increase the incentive for banks to take risks. Moreover, achieving an optimal deposit insurance scheme with an appropriate structure is an arduous task, with governments potentially absorbing all losses. This accelerates the tendency of banks to take further risks, which makes them more vulnerable to financial shocks (Cull et al. 2005, Demirgüç-Kunt et al. 2008 and Chernykh and Cole 2011).

In the case of official supervision, in general, it is argued that it could overcome market failure caused by imperfect information. Such supervision, together with enhanced monitoring and disciplining of banks, could consequently boost the governance of bank lending and reduce corruption (Beck et al. 2006b). In particular, it is argued that active supervisory agencies improve banks' efficiency and their ability to face any financial distress (Barth et al. 2004 and Barth et al. 2013b). Yet, it is counter-argued that supervisors may concentrate on promoting self-interest. For example, based on a self-interest hypothesis, supervisors may be able to conceal some supervisory information and to exchange it for private benefits (Boyer and Ponce, 2012), impeding financial stability (Beck et al. 2006b and Barth et al. 2013b). Additionally, powerful and more independent supervisors working in a weak governance-environment may hamper prudential supervision, creating a financial system which is less resistant to financial shocks (Melecky and Podpiera, 2013). It is also argued that supervision has varying impacts from country to country and from one financial environment to another (Ben Bouheni, 2014). In general, powerful and independent supervisory authorities in a well-developed financial system are less prone to financial 
shocks, while supervisory authorities in poor financial-governance environments could be more sensitive to financial distress (Chortareas et al. 2012).

Banks' internal monitoring is believed to reduce credit risk through the reduction of asymmetric information problems between banks and borrowers (Winton, 1995). It also enhances internal governance and thereby boosts stability in financial institutions. It is almost a consensus about the active role of governance in enhancing stability in the financial system. Kirkpatrick (2009) provided substantial evidence that weaknesses in the implementation of governance principles have contributed to the failures of banks, as well as poor risk management due to inaccuracies in conveying information and also an inadequate disclosure of predicted risk.

\subsection{Effects of market structure, institutional quality and economic environment on stability}

There are two conflicting views on the relationship between concentration (or competition) and financial stability (Uhde and Heimeshoff 2009 and Fu et al. 2014). The traditional view adopts the concentration-fragility perspective. Highly concentrated banking systems may boost market power, reducing competition in financial services. This may lead to increased loan rates and the market becomes prone to loan defaults (Beck et al. 2006a). See also Fu et al. (2014). On the other hand, the concentration-stability advocators emphasise that high concentration produces greater competition in an optimal market structure, obliging banks to lower interest rates. Further, concentration in the financial system may tend to lead to larger, better-diversified banks, which enhances stability in banking. Moreover, banks in a concentrated financial system are less prone to insolvency because of a strong capital buffer. It is also argued that the possibility of economies of scale and scope would enable them to achieve higher profits (Mirzaei and Moore, 2014). Regulators find that fewer market players can improve effective supervision, enhance monitoring and reduce the risk of contagion across banks (Beck et al., 2006a).

During the financial crisis, governments adopted a majority of stakes in most of the beleaguered financial institutions through bailouts in developed countries. This started the debate about whether government-owned banks enhance financial soundness (Nsengiyumva 2016). Three alternative theories can explain the relationship between government ownership and financial stability: the social, political and agency theories. The classical view 
is based on the social perspective, which suggests that government ownership is instrumental in addressing market failures, thus improving public welfare (Stiglitz 1993). The political perspective considers government-owned banks as a tool for implementing the individual goals of politicians (Shleifer and Vishny 1994), e.g. providing financial support for favoured enterprises or increasing employment for their supporters (Shleifer 1998). The agency perspective shares features with the social perspective to the extent that it aims to improve social welfare, however, this perspective generates weak management, misallocation of funds and corruption as a result of government bureaucracy (Banerjee, 1997). Hence, if the political or agency hypothesis holds, the government-owned banks may be a cause of instability.

The liberty of individuals and institutions is one of the most important pillars of economic development that has been pursued to achieve economic goals and to improve financial stability. Financial institutions can efficiently control their costs and reduce risk through the reduction of constraints (Chortareas et al. 2013). It surely exerts a preferable impact on the development of financial intermediaries (Hafer 2013). It is also argued that a high level of economic freedom creates greater political stability and thus reduces uncertainty in the financial system (Blau et al. 2014).

Significant academic efforts have aimed to identify the link between macroeconomic indicators and financial stability. Such as economic growth and inflation are found to affect the level of bank capitalisation and the quality of banks' assets (Schaeck and Cihak 2012). For example, Ayuso et al. (2004) and Jokipii and Milne (2008) argued the need for steady economic growth to enhance banks' capital buffers and improve financial soundness. Boyd et al. (2005) provided strong evidence that unstable economic growth increases uncertainty about a financial system's future. With regard to inflation, it is often seen as an obstacle to stability in the financial markets. An inflationary environment may raise a bank's incentive to increase loan rates so banks may gain more income. Hence, it may impede financial soundness by increasing the probability of borrowers' default (Tan and Floros 2012).

\section{Methodology, variables and data}

\subsection{Methodology}

The study utilises the CAMELS-DEA model for estimating a dependent variable, i.e. bank stability. The estimated bank stability is then regressed on regulations, supervision and other 
determinants in order to investigate the multifaceted effects on financial stability. A quantile regression $(\mathrm{QR})$ is applied for estimation.

Bank behaviour studies usually rely on a one-dimensional risk indicator such as a Zscore, non-performing loans, credit ratings, return on equity or capital ratios. These indicators do not reflect bank-specific characteristics and may contain some measurement errors because of differences in measurement for on- and off-balance issues (Klomp and De Haan, 2012). There is, therefore, doubt about the ability of these indicators to capture banking risk. Although a non-unique set of indicators exists, the CAMELS indicators appear to have a significant capacity to assess banks' soundness with their combination of indicators (Wanke et al. 2016). We adopt the CAMELS combination as a proxy of bank stability. The financial dimensions of this combination are employed by regulators and supervisors to assess banks' overall health (Avkiran and Cai 2012, Klomp and De Haan 2012, Wanke et al. 2015, Wanke et al. 2016, Buch et al. 2016 and Calabrese et al. 2017). The original criteria of the categories of CAMELS ratings are, however, undisclosed and unavailable to the public, hence the proxy of each category is selected, based on data availability and prior studies (Jin et al. 2011, Avkiran and Cai 2012 and Wanke et al. 2016).

The components of CAMELS are as follows: Capital adequacy (C) is captured by total equity and treated as a desirable output. It should be maximised when more equity is conducive to less financial distress. Asset quality (A) is captured by loan loss provisions (LLP), which is an undesirable input and should be minimised. In a similar manner, management efficiency (M) has a proxy in the form of total expenses (personnel and operating) and is regarded as an undesirable input. However, earnings quality (E) has a proxy in the form of total net income and is maximised as a desirable output. Liquidity (L) is another desirable output that has a proxy in the form of total liquid assets. Sensitivity to market risk (S) is measured by total assets and treated as a desirable output because of the role of total assets in impeding default risk (Wanke et al., 2016). Table 1 lists the components of CAMELS with data sources.

\section{[Table 1 about here]}

CAMELS indicators are multi-dimensional risk indicators, being useful for assessing the financial vulnerability of banks (Klomp and De Haan, 2012). DEA is an efficient frontier technique which calculates comparative ratios of multi-weighted inputs to multi-weighted outputs by using linear programming for each decision-making unit (DMU) (Avkiran, 2011). 
Accordingly, the application of DEA to CAMELS serves to deal with, and interact amongst, multi-inputs and multi-outputs by minimising inputs and maximising outputs. This provides a distinct advantage over traditional risk ratios.

Note that a DEA model may suffer from some econometric problems with the negative values (Emrouznejad et al., 2010) and the number of DMUs, which should be at least twice the total number of output and input indicators (Dyson et al. 2001). Hence, we exclude DMUs with negative values and the number of DMUs can be expressed as:

$$
D M U s \geq 3(2 x * y)
$$

where $x$ is the total number of inputs and $y$ is the total number of outputs. DMUS is the number of banks (the decision-making units).

We build a combination model relying on CAMELS rates and standard outputoriented DEA, using a return-to-scale technique. Thus, the stability model can be written as (Thanassoulis 2001 and Emrouznejad et al. 2010):

$$
\begin{array}{ll}
\text { Max t. } & \sum_{j}^{h} \lambda_{j} x_{i j} \leq x_{i j_{0}} ; \quad \forall i \\
& \sum_{j}^{j} \lambda_{j} y_{r j} \geq h y_{r j_{o}} ; \quad \forall r \\
& \sum_{j} \lambda_{j}=1 \\
& \lambda_{j} \geq 0 ; \quad \forall j, h \text { free }
\end{array}
$$

The efficiency of DMUS is measured by the optimal value of $h$, which reflects the stability level for each bank, $j$. $x$ refers to input and $y$ refers to output. $i$ is the actual value of inputs $\left\{x_{i j} ; i=1, \ldots, m\right\}$ and $r$ is the actual value of outputs $\left\{y_{r j} ; r=1, \ldots, s\right\}$.

The empirical model is based on QR, which treats the potential heterogeneity problem by exploring a range of conditions related to quantile functions (Koutsomanoli-Filippaki and Mamatzakis 2011). QR is designed to estimate the median of conditional distribution, and it is robust with outliers and avoids the assumption that 'error terms are identically distributed at all points of the conditional distribution' (Klomp and De Haan 2012). We use a multiplicative model, which is particularly designed to take account of generated heteroscedasticity and simultaneity data (Cameron and Trivedi 2009 and Klomp and De Haan 2012). The baseline of our QR can be written as: 


$$
Q_{\tau i j t}\left(C A M E L S_{i j t} \mid X_{j t}\right)=\alpha_{\tau i j t}+\beta_{\tau 1} C A M E L S_{i j t-1}+\beta_{\tau k} X_{k i j t-1}+\varepsilon_{i . t}+\varepsilon_{j . t}
$$

$C A M E L S_{i j t}$ refers to bank stability for bank $i$ in country $j$ at time $t$. The lagged dependent variable specified in the model accounts for autoregression. In order to address simultaneity and endogeneity, we take one lag in all explanatory variables (Klomp and De Haan, 2012). $X_{k i j t-1}$ is a lagged explanatory variable of type $k$, namely, Core Profitability Model, capital regulation index, activity restrictions, deposit insurance, private monitoring index, official supervisory power, government-owned banks, Herfindahl-Hirschman index (HHI), business freedom index, GDP, and inflation ${ }^{2}$. The error terms, $\varepsilon_{i, t}$ and $\varepsilon_{j, t}$, reflect errors in bank and country, respectively. Note that country and yearly dummies are included in estimating Eq. $(3)^{3}$. The regression is estimated for $\tau$ (quantiles), where:

$$
\text { Quantiles }=0<\tau<1
$$

The quantiles $\tau$ are the tenth, twenty-fifth, fiftieth, seventy-fifth, and ninetieth ${ }^{4}$.

The standard OLS regression model is given by:

$$
E\left(y_{i} \mid x_{i}\right)=\beta_{0}+\beta_{1} x_{i}
$$

Eq. (5) can be written as:

$$
y_{i}=\beta_{1}+\beta_{2} x_{i}+u_{i}
$$

where the error $u_{i}$ is satisfied by $E\left(y_{i} \mid x_{i}\right)=0$.

The quantile model $Q_{q}\left(y_{i} \mid x_{i}\right)$ is analogous to $E\left(y_{i} \mid x_{i}\right)$ in Eq. (5) but does not take into account the distribution function of $u_{i}$. The quantile model is written as:

$$
Q_{q}\left(y_{i} \mid x_{i}\right)=\beta_{1}+\beta_{2} x_{i}+F_{u_{i}}^{-1}(q)
$$

where $F_{u_{i}}$ is the distribution function of $u_{i}$ and conditional or dependent on $x_{i}$. Since this may lead to heteroskedasticity in error terms (Cameron and Trivedi 2009), we apply 1000 bootstrap replications so as to enhance the adequacy of the standard error (Hahn 1995).

We examine our quantile model by distinguishing the business model in banks, bank size and different stages of economic development across countries (Haas and Murphy 2003

\footnotetext{
${ }^{2}$ These explanatory variables are described in Section 3.2.

${ }^{3}$ Yearly dummies is likely to capture the effect of the sub-prime financial crisis during the sample period.

${ }^{4}$ We also derived quantile-varying estimates with an increment of 0.05 per quantile, which reflects 19 quantiles from 0.05 to 0.95 to ensure the robustness of our results (Lee and Li, 2012). The results are not presented in this paper in order to save space, but available from the authors upon request.
} 
and Thompson et al. 2006). We also re-estimate the effect of the explanatory variables on bank stability using a two-stage least squares (2SLS) instrumental regression model (Lee and Li 2012 and Klomp and De Haan 2012).

\subsection{Definition of explanatory variables}

Efficient banks which maximise profitability are more likely to build strong capital buffers and are less liable to be exposed to financial distress (Athanasoglou et al. 2008, Uhde and Heimeshoff 2009 and Vives 2011). We specifies the Core Profitability Model (CPM) as a proxy for maximising profits and minimising costs by using the input-output technical efficiency approach with Eq. (2) (Avkiran 2011 and Avkiran and Cai 2012). CPM consists of two cost inputs (total interest expenses and total non-interest expenses) and two profit outputs (gross interest and dividend income and total non-interest operating income).

The capital regulatory index is specified in the model as a measurement of overall capital regulation. The index consists of overall capital stringency which evaluates the amount of capital that banks should hold and also initial capital stringency which measures certain funds that may initially be utilised to capitalise a bank (Barth et al., 2004). The variable of activity restrictions indicates the extent to which individual banks are able to handle and underwrite securities, to sell and underwrite insurance and to invest in property (Barth et al., 2004). Deposit insurance determines whether deposit insurance authorities have the power to make a decision to intervene in a bank and to take legal action against a bank's officers or directors. This variable is also used to determine whether deposit insurance authorities have ever taken any legal action against a bank's officers or directors (Barth et al., 2013a).

Private monitoring index measures whether there are incentives to privately monitor banks. The official supervisory power evaluates whether the supervisory power has the power to take concrete actions to correct and prevent problems (Barth et al., 2013a). The variable of Government-owned banks reflects the percentages of a banking system's equity which are owned or controlled by a government (Barth et al., 2013a).

We utilise the Herfindahl-Hirschman Index (HHI) as a proxy of concentration in the banking sector. It captures, through squaring, the market share (deposits) for each bank competing in the banking sector in each country, and has a range from zero to 10.000 points (Al-Muharrami et al., 2006). 
This study relies on the worldwide governance indicators (WGI) to investigate the impact of governance on financial stability. These indicators reflect six dimensions of governance: voice and accountability, government effectiveness, the rule of law, political stability, quality of regulation and control of corruption (Kaufmann et al., 2011). We include the governance index by calculating the average value of all governance dimensions. While the governance index reflects only the quality of the legal and regulatory environment, the business freedom index is more comprehensive. The latter is based on 10 essential dimensions grouped into four broad pillars: i) the rule of law, which includes property rights and freedom from corruption, ii) limited government, which combines fiscal freedom and government spending, iii) regulatory efficiency, which refers to business freedom, labour freedom and monetary freedom and iv) the open market, which reflects freedom of trade, investment and finance.

This study also includes the natural logarithm of GDP to capture the influence of an economic growth rate on financial stability. The consumer price index is used for inflation.

Table 1 presents the sources of these variables.

\subsection{Data and descriptive analysis}

In our study, the unbalanced panel data of 2210 banks are used over 17 years from 2000 to 2016. The sample includes commercial banks, investment banks and bank holding companies in 47 European countries. See Appendix for the number of banks for each country. Unlike most financial literature, which has concentrated on listed banks (e.g. Demirgüç-Kunt and Huizinga 2010 and Altunbas et al. 2011), our sample includes both listed and unlisted banks. Unlisted banks usually reflect significant numbers of small banks (Köhler, 2015) and so the inclusion of unlisted banks is likely to articulate the effect of variation in business models and bank size on financial stability (Demsetz and Strahan, 1997). The data set excludes the following: i) banks that do not report the values of total assets or LLP. ii) banks with headquarters outside European countries, iii) banks with fewer than three years of consecutive observations, and iv) banks with outliers in figures, which may reflect errors in measurement and hence may influence the stability score, specifically when utilising the DEA technique. 


\section{[Table 2 about here]}

The summary statistics of the indicators are found in Table 2. Winsorising is used for the CAMELS and CPM modelling 5 . The values in the table reflect the overall average for all sample countries. CAMELS has an average of $52.3 \%{ }^{6}$. A large standard deviation suggests that CAMELS varies widely across banks. The average of the capital regulation index is approximately 6.4 out of 10. The emerging European markets have had a significant negative impact on the overall score of capital regulation index, while advanced markets are, in general, above the average level, reflecting the stringent capital buffers held in banks in advanced countries. European countries, in general, appear to have relatively fewer restrictions regarding non-traditional bank activities with an average of 5.8 out of 12 , and deposit insurance seems to be weak with 1.1 out of 4 . Moreover, Government-owned banks is relatively low at approximately $17.8 \%$. It indicates a remarkable shift in Russia and former Eastern European countries in the context of privatisation of financial institutions. The average value of $H H I$ at 1802 points seems to indicate relatively highly concentrated markets in Europe ${ }^{7}$. A figure of $3.13 \%$ GDP growth suggests stable economic growth. A relatively high inflation rate of $4.6 \%$ may reflect monetary stimulus policies in some European countries and/or may be due to a faster growth in emerging European countries.

\section{[Table 3 about here]}

The cross-correlation matrix between the variables is presented in Table 3 . The matrix does not show significant correlations between variables except for the correlation coefficient between governance index and business freedom index, which records at approximately 0.89 . Hence, we separately specify each variable in the model: the business freedom index in the main analysis and the governance index in the robustness analysis.

\footnotetext{
${ }^{5}$ Recall that both are estimated based on Eq. [2].

${ }^{6}$ The estimated stability scores for individual countries are not presented to save space, but available upon request from the authors.

${ }^{7}$ The US merger guideline suggests that HHI exceeding 1800 is deemed to be a highly concentrated market. The EU guideline is similar to that of the US.
} 


\section{Empirical results}

\subsection{Main model}

The estimated parameters of Eq. (3) are presented in Table 4 with five quantile results of Q0.10, Q0.25, Q0.50, Q0.75 and Q0.90. The results of OLS are also presented for comparison at Column (6). OLS depends on the approximation of the mean function of conditional distribution, which does not provide a complete picture of the influence of explanatory variables on stability dispersion across banks. Quantiles can deliver a clear picture about the influence of explanatory variables by distinguishing high and low stability banks. Fig. 1 shows the distribution of explanatory variables.

\section{[Table 4 and Figure 1 are about here]}

Table 4 indicates the significant positive impact of most Core Profitability Model $(C P M)$ quartiles at least at the $10 \%$ level on financial stability, except for Q0.25. The distribution of impact in Fig 1 indicates the sharp increase at Q0.90. We also observe a significant variation in the capital regulation index estimates across quantiles with regard to their influence on bank stability. This is particularly evident in Table 4 with the tails of the distribution with Q0.10 at approximately 0.174 that is compared with Q0.90 at 0.955 . See Figure 1 which shows an upward movement.

Greater activity restrictions have a highly significant negative influence on bank stability among stable banks, since the coefficients are significant for Q0.75 and Q0.90 at the $1 \%$ and $5 \%$ level, respectively. The result suggests that a greater restriction in the number of non-traditional financial activities may reduce the ability of banks to diversify risk, thus impeding their stability. The impact of deposit insurance on bank stability is also negative and mostly highly significant across various quantiles. Deposit insurance may motivate a bank to relax its restrictions on lending and disrupt the ability of banks to maintain stability. This effect seems to be stronger among high-stability banks, as we find that the largest coefficient is found at Q0.90 with -1.6.

With respect to private monitoring index, we also observe a significant negative impact on bank stability across different quantiles. Similarly, the coefficient on official supervisory power shows a negative effect on bank stability. It is argued that a robust supervision is likely to boost the governance of bank lending, contributing to stability (Beck et al. 2006b), yet such a role does not seem to be present in our study. Our result suggests 
the re-emphasis of the assessment of risk management by supervisors. The empirical analysis indicates that government-owned banks appear to jeopardise bank stability across all quantiles, albeit, the stronger effect is felt more at the highest quantiles. The finding demonstrates that bureaucracy in government agencies may lead to weak management, corruption and misallocation of resources, decreasing stability in the banking system.

Concentration proxied by $H H I$ has a positive significant influence on stability from Q0.10 to Q0.75. This result is consistent with the concentration-stability approach (Uhde and Heimeshoff, 2009). Concentration may generate fewer market players, enhancing monitoring power and stability in the banking industry. Yet, concentration does not seem to exert any impact on already stable banks as the coefficient is insignificant at Q0.90. We also observe a significant positive effect of the business (economic) freedom index on bank stability.

With regard to macroeconomic factors, the empirical results reveal that GDP has a positive and significant impact on stability across most quantiles. This can be attributed to the decreasing probability of default because of stable economic growth. The variable of inflation is not well-determined, and this may have mixed implications for the banking sector. It is often the case that banks may benefit from inflation by gaining more profit due to a higher spread between lending and borrowing rates, however, an inflationary environment may increase the uncertainty in the economy, impeding stability in the banking sector.

It is noteworthy that, in general, banks in high-stability groups are more heavily affected by explanatory variables compared with banks in low-stability groups. A comparison of the QR estimates with the OLS estimates indicates that employing the OLS may, indeed, lead to misleading conclusions regarding the relationship between bank stability and regulations and other determinants.

\subsection{Business models}

In this section, we re-estimate the QR by splitting the sample into three classifications of business models: i) commercial banks, ii) investment banks and iii) bank holding companies. The empirical results are found in Table 5a.

\section{[Table 5a and 5b about here]}

Our result highlights that capital regulation index is, in general, consistent with the main results in Table 4 for commercial banks. The estimated coefficients are positive and 
significant across different quantiles in commercial banks, though it has a marginal impact on stability in other types of banks. This result reflects the nature of risk in commercial banks, one of which lies in holding loans, and where banks need to be facilitated with adequate capital as a cushion against potential non- performing loans (Chateau and $\mathrm{Wu}, 2007$ ). On the other hand, investment banks and bank holding companies have multifaceted businesses including brokering, trading, core investments and fund management, thus, capital adequacy alone may not be able to promote stability (Radić et al., 2012). Activity restrictions are significantly negative for the median and higher quantiles in commercial banks and also bank holding companies; higher quantiles are adversely affected by a tightening of activity restrictions. Deposit insurance authority, Private monitoring index and Official supervisory power exert a significantly adverse effect on stability in commercial banks, whilst these effects are almost absent in investment banks and bank holding companies.

The coefficients of Government-owned banks are significantly negative in most quantiles and across different business models, albeit, we see a modest influence in the case of bank holding companies. The results reaffirm the initial main results that greater government ownership is a hindrance to bank stability. The estimates of the coefficients of $H H I$ are positive and significant mainly in commercial banks, suggesting commercial banks are more sensitive to concentrated markets. The positive effect of Business freedom index is also found only in commercial banks across all quantiles.

Overall, the empirical results in Table 5a indicate that commercial banks are more sensitive to regulatory shocks. This is not surprising since commercial banks are heavily framed by regulatory bodies as compared with other business models.

By extending the analysis of the business model, we also split the sample into listed and unlisted banks and generate separate estimates by using quantile regressions. Listed banks differ from unlisted banks in several ways. For instance, listed banks tend to have a more dispersed ownership structure than unlisted banks, providing greater scope for private benefits. In order to protect these benefits, managers of listed banks are likely to take fewer risks (Barry et al. 2011). However, listed banks tend to be closely monitored by the market, hence it is argued that the managers of listed banks expand into more risky non-interest income activities to generate a higher return (Köhler, 2015). Hence there is the possiblity that the impact of regulations and supervision on their stability may differ between lsited and unlisted banks. The results are found in Table $5 b$. 
The results for both listed and unlisted banks are, in general, in line with the main results in Table 4. However, it is found that the stability of unlisted banks tends to respond with more sensitivity to regulation and supervision, as compared with that of listed banks. Notably, Capital regulation index and Deposit insurance are statistically highly significant in unlisted banks at Q0.50, Q0.75 and Q0.90. It is interesting that a greater benefit from capital regulation is found in unlisted banks in terms of banks stability.

\subsection{Bank size}

In this section, we re-group our sample into large and small banks based on a median point ${ }^{8}$ in order to examine any particular features and to avoid bias due to bank size. The estimation results are presented in Table 6.

\section{[Table 6 about here]}

In general, the results are consistent with our primary findings. Banks are affected positively by CPM. With regard to the Capital regulation index, the positive significant coefficients are observed in lower quantiles in large banks, whereas in higher quantiles in small banks. This implies that in small banks, a high stability is likely to be maintained by the capital adequacy. Interestingly, while small banks are adversely affected by activity restrictions, large banks are not sensitive to the variable across most quantiles. However, size may prove costly for large banks in terms of deposit insurance, as evidenced by the significantly negative coefficients across all quantiles for large banks. The empirical findings also reveal the absence of effects derived from the Private monitoring index, Official supervisory power and Government ownership on the stability of large banks, meanwhile, the stability of small banks seems to be jeopardised by excessive monitoring and government intervention. HHI, Business freedom index and GDP are almost consistent with our main results in Table 4 across large and small banks.

Overall, the estimation results appear to demonstrate that smaller banks are more sensitive to the shocks from bank regulations, monitoring and supervisory powers.

\subsection{Economic development}

The new global financial system increases the depth of links between advanced and emerging economies. Thus, the crises in advanced economies are rapidly and significantly transmitted

\footnotetext{
${ }^{8}$ The median point of total assets among the banks is US\$1212.011 million.
} 
to emerging economies (Balakrishnan et al., 2011). Nonetheless, sophisticated application of governance, supervision and internal monitoring may enhance the resistance of advanced economies to crises. In contrast, poor governance may lead to elevated financial stress in emerging economies. In this section, we split our sample into 20 advanced and 27 emerging European countries ${ }^{9}$ in order to examine the impact of financial regulation and supervisory power in the different stages of economic development.

\section{[Table 7 about here]}

The empirical results are shown in Table 7. Amongst others, we can observe the opposite direction of the coefficients in Private monitoring index and Official supervisory power where the positive influence is found for advanced economies and negative for emerging economies. The possible explanation lies in the quality of supervision. For instance, sophisticated supervisory agencies may enhance private monitoring by reducing the barriers to the conveyance of information, thereby boosting bank stability in advanced economies. Meanwhile, it is argued that in emerging economies supervisors may use their power to generate their own benefits by weakening private monitoring, causing instability (Barth et al. 2004). The result also highlights that government-owned banks in advanced countries tend to suffer severely from instability. With regard to other variables, $C P M$, capital regulation index, HHI, business freedom index and GDP all have a positive impact on stability. In contrast, a perverse influence of activity restrictions, deposit insurance, and inflation is evident. These results are similar to our main findings in Table 4.

\subsection{Robustness checks}

\section{[Table 8 and Table 9 about here]}

Governance is one of the main pillars in any financial system and an essential instrument for improving stability. We modify the model specification by replacing Business freedom index with Governance index with six dimensions of the WGI to control for the effects of a country's governance level on bank stability (see Table 1 for six dimensions). The results are shown in Table 8 , where almost all explanatory variables maintain their significance and sign of their coefficients in accordance with the main findings. The coefficients on Governance index are positive and highly significant, suggesting that a better governance-environment helps to increase stability in the banking system. It is evidenced that the largest effect

\footnotetext{
${ }^{9}$ See Appendix.
} 
measured by the size of the coefficient (at 0.215) is found at a highest quantile of Q0.90, implying that better governance is conducive to more stable banks.

In order to address the possibility of the endogeneity problem, we employed two step estimators. In fact, bank capital regulations might be endogenous, especially when supervisors have obliged banks to raise capital in order to protect themselves against financial distress (Köhler 2015). In the first stage, we estimate capital regulation as an endogenous variable, with instrument variables to create the fitted values. Based on literature on financial regulation, specifically, we select IVs of ethnic fractionalisation and legal origins that are likely to contribute to the development in financial institutions (Barth et al. 2013b) ${ }^{10}$. We also include independence of supervision as an instrumental variable which measures the differences in independence from government across supervisory authorities (Klomp and De Haan 2012) ${ }^{11}$. In the second stage, we applied quantile regression by replacing the capital regulations with fitted values (Angrist et al. 1999).

Moreover, we estimated Generalised Method of Moments (GMM). Studies such as Akhter and Daly (2009) and Fonseca and González (2010) suggest that capital regulations and bank stability have a tendency to persist over time. Hence, we adopt dynamic panel model by incorporating the second lagged dependent variable among regressors, together with the second lag on capital regulation, to further check the robustness of our main results. This can help deal with inter-temporal risk and banking regulations.

The empirical results are found in Table 9. Overall, the results are supportive to the main results in Table 4. Note that the coefficients of Deposit insurance in regressions (4) and (5) and that of Official supervisory power in (6) are not significant amongst the key explanatory variables. Yet, given the fact that the signs on the coefficients are all consistent throughout the regressions, the robustness of the main results appears to be sustained.

\footnotetext{
${ }^{10}$ Ethnic fractionalisation is the average value of five different indices of ethnolinguistic fractionalisation. Legal origins identifies the origin of the company law or commercial code of each country. There are five origins: English common law, French commercial Code, German Commercial Code, Scandinavian Commercial Code and Socialist Laws. See Table 1 in Alesina et al. (2003) for a further description of data and sources.

11 The definition and data source are found in Table 1 in this paper.
} 


\section{Conclusion}

In this article, we provided further insight into the effects of financial regulation and supervision on bank stability. We examined the variations of business models, bank size and economic development through the CAMELS-DEA rating system combined with a quantile technique. The data set covers 2210 European banks from 2000 to 2016.

The main empirical results reveal that the capital regulation index variables have a positive influence on stability. The results re-emphasise the importance of capital adequacy for bank stability. The results also show the adverse impact of activity restrictions on stability, suggesting that restrictions in non-traditional financial activity jeopardises bank stability due to a lower degree of diversification. Other regulatory and supervisory variables also turn out to be causes of instability. In general, the banks in high-stability groups are more responsive to the shocks from regulations and supervision.

Clear variations are evident across different business models, where the explanatory variables for commercial banks are well-determined for expounding stability, whereas a weak effect of regulations and supervision on stability is found across investment banks and bank holding companies. This finding may not be surprising due to the fact that financial regulations are more heavily imposed on commercial banks. With regard to bank size, small banks are more sensitive to regulatory shocks as compared with large banks. This suggests the importance of financial regulation for small banks to help provide a buffer against financial distress. We also find that while the private monitoring index and official supervisory power are negative for stability across emerging economies, their effect is positive across advanced economies. This may indicate the better quality of monitoring and supervision for the advanced banks. Furthermore, our extended model reveals that governance is still the cornerstone of financial stability and has a positive impact on stability across the whole sample.

Financial regulation and supervision may enhance or impede stability. Indeed, financial policymakers should take into account such variations not only from the perspectives of legal and historical backgrounds across countries, but also from the perspectives of institutional backgrounds related to banks' business models, bank size and the stage of economic development. 
Appendix: Number of banks across advanced and emerging economies

\begin{tabular}{cccc}
\hline Emerging countries & No. of banks & \multicolumn{2}{c}{ Advanced countries No. of banks } \\
\hline ALBANIA & 13 & AUSTRIA & 68 \\
ANDORRA & 3 & BELGIUM & 23 \\
BELARUS & 21 & DENMARK & 40 \\
BOSNIA AND & 27 & FINLAND & 26 \\
HERZEGOVINA & 20 & FRANCE & 121 \\
BULGARIA & 30 & GERMANY & 155 \\
CROATIA & 19 & GREECE & 9 \\
CYPRUS & 17 & ICELAND & 11 \\
CZECH REPUBLIC & 9 & IRELAND & 15 \\
ESTONIA & 1 & ITALY & 89 \\
GIBRALTAR & 17 & LIECHTENSTEIN & 1 \\
HUNGARY & 4 & LUXEMBOURG & 57 \\
KOSOVO & 19 & MONACO & 1 \\
LATVIA & 9 & NETHERLANDS & 33 \\
LITHUANIA & 15 & NORWAY & 23 \\
MACEDONIA (FYROM) & 12 & PORTUGAL & 33 \\
MALTA & 8 & SPAIN & 51 \\
MONTENEGRO & 39 & SWEDEN & 38 \\
POLAND & 12 & SWITZERLAND & 139 \\
REPUBLIC OF MOLDOVA & 21 & UNITED KINGDOM & 136 \\
ROMANIA & 702 & ICELAND & 11 \\
RUSSIAN FEDERATION & 4 & & \\
SAN MARINO & 27 & & 2210 \\
SERBIA & 14 & & \\
SLOVAKIA & 17 & & \\
SLOVENIA & 38 & & \\
TURKEY & 23 & & \\
UKRAINE & & & \\
TOtal & & & \\
Grand Total & 141 & & \\
\hline & & & \\
\hline & & & \\
\hline
\end{tabular}

Classification of Advanced and emerging European countries are based on MSCI (https:/www.msci.com/europe) and BankScope. 


\section{References}

ALESIA, A., DEVLEESCHAUWER, A., EASTER, W., KURLAT, S. \& WACZIARG, R. 2003. Fractionalization. Journal of Economic Growth, 8(2), 155-194.

AL-MUHARRAMI, S., MATTHEWS, K. \& KHABARI, Y. 2006. Market structure and competitive conditions in the Arab GCC banking system. Journal of Banking \& Finance, 30, 3487-3501.

ALTMAN, E. I. 1968. Financial ratios, discriminant analysis and the prediction of corporate bankruptcy. The journal of finance, 23, 589-609.

ALTMAN, E. I., HALDEMAN, R. G. \& NARAYANAN, P. 1977. Zeta tm analysis a new model to identify bankruptcy risk of corporations. Journal of banking \& finance, 1 , 29-54.

ALTUNBAS, Y., MANGANELLI, S. \& MARQUES-IBANEZ, D. 2011. Bank risk during the financial crisis: do business models matter?

ANGINER, D., DEMIRGUC-KUNT, A. \& ZHU, M. 2014. How does deposit insurance affect bank risk? Evidence from the recent crisis. Journal of Banking \& finance, 48, 312-321.

ANGRIST, J.D., IMBENS, G.W. \& KRUEGER, A.B. 1999. Jackknife instrumental variables estimation. Journal of Applied Econometrics, 14(1), 57-67.

ATHANASOGLOU, P. P., BRISSIMIS, S. N. \& DELIS, M. D. 2008. Bank-specific, industry-specific and macroeconomic determinants of bank profitability. Journal of international financial Markets, Institutions and Money, 18, 121-136.

AVKIRAN, N. K. 2011. Association of DEA super-efficiency estimates with financial ratios: Investigating the case for Chinese banks. Omega, 39, 323-334.

AVKIRAN, N. K. \& CAI, L. Predicting bank financial distress prior to crises. New Zealand Finance Colloquium, 2012.

AYADI, R., ARBAK, E. \& PIETER DE GROEN, W. 2012. Regulation of European banks and business models: towards a new paradigm? Centre for European Policy Studies, Forthcoming.

AYUSO, J., PÉREZ, D. \& SAURINA, J. 2004. Are capital buffers pro-cyclical?: Evidence from Spanish panel data. Journal of financial intermediation, 13, 249-264.

BABECKÝ, J., HAVRÁNEK, T., MATĚJŮ, J., RUSNÁK, M., ŠMÍDKOVÁ, K. \& VAŠÍČEK, B. 2014. Banking, debt, and currency crises in developed countries: Stylized facts and early warning indicators. Journal of Financial Stability, 15, 1-17.

BALAKRISHNAN, R., DANNINGER, S., ELEKDAG, S. \& TYTELL, I. 2011. The transmission of financial stress from advanced to emerging economies. Emerging Markets Finance and Trade, 47, 40-68.

BANERJEE, A. V. 1997. A theory of misgovernance. The Quarterly Journal of Economics, 1289-1332.

BARAKAT, A. \& HUSSAINEY, K. 2013. Bank governance, regulation, supervision, and risk reporting: Evidence from operational risk disclosures in European banks. International Review of Financial Analysis, 30, 254-273.

BARRY, T.A., LEPETIT, L. \& TARAZI, A. 2011. Ownership structure and risk in publicly held and privately owned banks. Journal of Banking \& Finance, 35(5), 1327-1340.

BARTH, J. R., CAPRIO, G. \& LEVINE, R. 2004. Bank regulation and supervision: what works best? Journal of Financial intermediation, 13, 205-248.

BARTH, J. R., CAPRIO JR, G. \& LEVINE, R. 2013a. Bank Regulation and Supervision in 180 Countries from 1999 to 2011. Journal of Financial Economic Policy, 5, 111-219. 
BARTH, J. R., LIN, C., MA, Y., SEADE, J. \& SONG, F. M. 2013b. Do bank regulation, supervision and monitoring enhance or impede bank efficiency? Journal of Banking \& Finance, 37, 2879-2892.

BECK, T., DEMIRGÜÇ-KUNT, A. \& LEVINE, R. 2006a. Bank concentration, competition, and crises: First results. Journal of Banking \& Finance, 30, 1581-1603.

BECK, T., DEMIRGÜÇ-KUNT, A. \& LEVINE, R. 2006b. Bank supervision and corruption in lending. Journal of Monetary Economics, 53, 2131-2163.

BEN BOUHENI, F. 2014. Banking regulation and supervision: can it enhance stability in Europe? Journal of Financial Economic Policy, 6, 244-269.

BESANKO, D. \& KANATAS, G. 1993. Credit market equilibrium with bank monitoring and moral hazard. Review of Financial studies, 6, 213-232.

BLAU, B. M., BROUGH, T. J. \& THOMAS, D. W. 2014. Economic freedom and the stability of stock prices: A cross-country analysis. Journal of International Money and Finance, 41, 182-196.

BOOT, W. A. \& GREENBAUM, S. I. 1992. Bank regulation, reputation and rents: Theory and policy implications.

BORIO, C. 2003. Towards a macroprudential framework for financial supervision and regulation? CESifo Economic Studies, 49, 181-215.

BOYD, J. H. \& GRAHAM, S. L. 1986. Risk, regulation, and bank holding company expansion into nonbanking. Quarterly Review, 2-17.

BOYD, J. H., KWAK, S. \& BRUCE, D. 2005. The real output losses associated with modern banking crises. Journal of money, credit, and banking, 37, 977-999.

BOYER, P. C. \& PONCE, J. 2012. Regulatory capture and banking supervision reform. Journal of Financial Stability, 8, 206-217.

BUCH, C. M., BUCH, C. M., HILBERG, B., OUML, RN \& TONZER, L. 2016. Taxing banks: An evaluation of the German bank levy. Journal of banking \& finance, 72, 5266.

CALABRESE, R., DEGL'INNOCENTI, M. \& OSMETTI, S. A. 2017. The effectiveness of TARP-CPP on the US banking industry: A new copula-based approach. European Journal of Operational Research, 256, 1029-1037.

CAMERON, A. C. \& TRIVEDI, P. K. 2009. Microeconometrics using stata, Stata Press College Station, TX.

CAPPIELLO, L., KADAREJA, A. \& MANGANELLI, S. 2010. The impact of the Euro on equity markets, Journal of Financial and Quantitative Analysis 45, 473-502.

CHATEAU, J.-P. \& WU, J. 2007. Basel-2 capital adequacy: Computing the 'fair'capital charge for loan commitment 'true'credit risk. International Review of Financial Analysis, 16, 1-21.

CHERNYKH, L. \& COLE, R. A. 2011. Does deposit insurance improve financial intermediation? Evidence from the Russian experiment. Journal of Banking \& Finance, 35, 388-402.

CHORTAREAS, G. E., GIRARDONE, C. \& VENTOURI, A. 2012. Bank supervision, regulation, and efficiency: Evidence from the European Union. Journal of Financial Stability, 8, 292-302.

CHORTAREAS, G. E., GIRARDONE, C. \& VENTOURI, A. 2013. Financial freedom and bank efficiency: Evidence from the European Union. Journal of Banking \& Finance, 37, 1223-1231.

CHUANG, C.D., KUAN, C.M. \& LIN, H.Y. 2009. Causality in quantiles and dynamic stock return-volume relations. Journal of Banking and Finance 33, 1351-1360.

ČIHÁK, M., DEMIRGÜÇ-KUNT, A., FEYEN, E. \& LEVINE, R. 2012. Benchmarking financial systems around the world. World Bank Policy Research Working Paper. 
COLE, R. A. \& GUNTHER, J. W. 1995. Separating the likelihood and timing of bank failure. Journal of Banking \& Finance, 19, 1073-1089.

CONSTANTINESCU, L. A. 2015. Challenges for Deposit Insurance and Financial Stability in European Cooperative Banks. Knowledge Horizons. Economics, 7, 43.

CREEL, J., HUBERT, P. \& LABONDANCE, F. 2015. Financial stability and economic performance. Economic Modelling, 48, 25-40.

CROCKETT, A. 1997. Why is financial stability a goal of public policy? Economic ReviewFederal Reserve Bank of Kansas City, 82, 5.

CULL, R., SENBET, L. W. \& SORGE, M. 2005. Deposit insurance and financial development. Journal of Money, Credit and Banking, 43-82.

DAVIS, J. H., SCHOORMAN, F. D. \& DONALDSON, L. 1997. Toward a stewardship theory of management. Academy of Management review, 22, 20-47.

DELIS, M. 2015. Bank risk, financial stability, and the role of regulation. Journal of banking and finance, 61, 1-2.

DEMIRG, XFC, XE, KUNT, A. \& DETRAGIACHE, E. 1998. The Determinants of Banking Crises in Developing and Developed Countries. Staff Papers (International Monetary Fund), 45, 81-109.

DEMIRGÜÇ-KUNT, A. \& DETRAGIACHE, E. 2002. Does deposit insurance increase banking system stability? An empirical investigation. Journal of monetary economics, 49, 1373-1406.

DEMIRGÜÇ-KUNT, A. \& DETRAGIACHE, E. 2011. Basel Core Principles and bank soundness: Does compliance matter? Journal of Financial Stability, 7, 179-190.

DEMIRGÜÇ-KUNT, A. \& HUIZINGA, H. 2010. Bank activity and funding strategies: The impact on risk and returns. Journal of Financial Economics, 98, 626-650.

DEMIRGÜÇ-KUNT, A., KANE, E. J. \& LAEVEN, L. 2008. Determinants of depositinsurance adoption and design. Journal of Financial Intermediation, 17, 407-438.

DEMSETZ, R. S. \& STRAHAN, P. E. 1997. Diversification, size, and risk at bank holding companies. Journal of money, credit, and banking, 300-313.

DEYOUNG, R. 1998. Management quality and X-inefficiency in national banks. Journal of Financial Services Research, 13, 5-22.

DONALDSON, L. \& DAVIS, J. H. 1991. Stewardship theory or agency theory: CEO governance and shareholder returns. Australian Journal of management, 16, 49-64.

DYSON, R. G., ALLEN, R., CAMANHO, A. S., PODINOVSKI, V. V., SARRICO, C. S. \& SHALE, E. A. 2001. Pitfalls and protocols in DEA. European Journal of operational research, 132, 245-259.

EMROUZNEJAD, A., ANOUZE, A. L. \& THANASSOULIS, E. 2010. A semi-oriented radial measure for measuring the efficiency of decision making units with negative data, using DEA. European Journal of Operational Research, 200, 297-304.

ENGLE, R.F. \& MANGANELLI, S., 2004. CAViaR: conditional autoregressive value at risk by regression quantiles. Journal of Business and Economic Statistics 22, 367-381

EUROPEAN CENTRAL, B. 2005. Assessing financial stability: conceptual boundaries and challenges.

FONSECA, A.R. \& GONZALEZ, F. 2010. How bank capital buffers vary across countries: The influence of cost of deposits, market power and bank regulation. Journal of Banking \& Finance, 34(4), 892-902.

FU, X. M., LIN, Y. R. \& MOLYNEUX, P. 2014. Bank competition and financial stability in Asia Pacific. Journal of Banking \& Finance, 38, 64-77.

FURLONG, F. T. \& KEELEY, M. C. 1989. Capital regulation and bank risk-taking: A note. Journal of Banking \& Finance, 13, 883-891. 
GABAIX, X. \& LANDIER, A. 2008. Why Has CEO Pay Increased so Much? The Quarterly Journal of Economics, 123, 49-100.

GAMBACORTA, L. \& MISTRULLI, P. E. 2004. Does bank capital affect lending behavior? Journal of Financial intermediation, 13, 436-457.

GARRY, J. S. \& SCHINASI, G. 2004. Defining financial stability. IMF Working Paper, 2004: 128-190.

HAAS, D. A. \& MURPHY, F. H. 2003. Compensating for non-homogeneity in decisionmaking units in data envelopment analysis. European Journal of Operational Research, 144, 530-544.

HAFER, R. W. 2013. Economic freedom and financial development: International evidence. Cato Journal, 33, 111-126.

HAHN, J. 1995. Bootstrapping quantile regression estimators. Econometric Theory, 11, 105121.

HAKENES, H. \& SCHNABEL, I. 2011. Capital regulation, bank competition, and financial stability. Economics Letters, 113, 256-258.

HANNAN, T. H. \& HANWECK, G. A. 1988. Bank insolvency risk and the market for large certificates of deposit. Journal of Money, Credit and Banking, 20, 203-211.

HOLLO, D., KREMER, M. \& LO DUCA, M. 2012. CISS-a composite indicator of systemic stress in the financial system.

IANNOTTA, G. 2007. Ownership structure, risk and performance in the European banking industry. Journal of banking \& finance, 31, 2127-2149.

ISSING, O. 2003. Monetary and financial stability: is there a trade-off? BIS Papers, 18, 1623.

JENSEN, M. C. 1986. Agency cost of free cash flow, corporate finance, and takeovers. Corporate Finance, and Takeovers. American Economic Review, 76.

JIN, J. Y., KANAGARETNAM, K. \& LOBO, G. J. 2011. Ability of accounting and audit quality variables to predict bank failure during the financial crisis. Journal of Banking \& Finance, 35, 2811-2819.

JOKIPII, T. \& MILNE, A. 2008. The cyclical behaviour of European bank capital buffers. Journal of banking \& finance, 32, 1440-1451.

KAUFMANN, D., KRAAY, A. \& MASTRUZZI, M. 2011. The worldwide governance indicators: methodology and analytical issues. Hague Journal on the Rule of Law, 3, 220-246.

KIM, D. \& SANTOMERO, A. M. 1988. Risk in banking and capital regulation. The Journal of Finance, 43, 1219-1233.

KIRKPATRICK, G. 2009. The corporate governance lessons from the financial crisis. OECD Journal: Financial Market Trends, 2009, 61-87.

KLOMP, J. \& DE HAAN, J. 2012. Banking risk and regulation: Does one size fit all? Journal of Banking \& Finance, 36, 3197-3212.

KÖHLER, M. 2015. Which banks are more risky? The impact of business models on bank stability. Journal of Financial Stability, 16, 195-212.

KOUTSOMANOLI-FILIPPAKI, A. I. \& MAMATZAKIS, E. C. 2011. Efficiency under quantile regression: What is the relationship with risk in the EU banking industry? Review of Financial Economics, 20, 84-95.

KUMAR, P. R. \& RAVI, V. 2007. Bankruptcy prediction in banks and firms via statistical and intelligent techniques-A review. European journal of operational research, 180, $1-28$.

LAEVEN, L. \& LEVINE, R. 2007. Is there a diversification discount in financial conglomerates? Journal of Financial Economics, 85, 331-367. 
LEE, B. S. \& LI, M.-Y. L. 2012. Diversification and risk-adjusted performance: A quantile regression approach. Journal of Banking \& Finance, 36, 2157-2173.

LOAYZA, N. V. \& RANCIERE, R. 2006. Financial development, financial fragility, and growth. Journal of Money, Credit and Banking, 1051-1076.

MÄNNASOO, K. \& MAYES, D. G. 2009. Explaining bank distress in Eastern European transition economies. Journal of Banking \& Finance, 33, 244-253.

MELECKY, M. \& PODPIERA, A. M. 2013. Institutional structures of financial sector supervision, their drivers and historical benchmarks. Journal of Financial Stability, 9, 428-444.

MERGAERTS, F. \& VANDER VENNET, R. 2016. Business models and bank performance: A long-term perspective. Journal of Financial Stability, 22, 57-75.

MIRZAEI, A. \& MOORE, T. 2014. What are the driving forces of bank competition across different income groups of countries? Journal of International Financial Markets, Institutions and Money, 32, 38-71.

MURPHY, K. J. 1985. Corporate performance and managerial remuneration: An empirical analysis. Journal of accounting and economics, 7, 11-42.

NSENGIYUMVA, J. 2016. Does Government Ownership Negatively Affect Soundness of Banks? New Evidence. International Review of Management and Business Research, 5, 743.

PASIOURAS, F., GAGANIS, C. \& ZOPOUNIDIS, C. 2006. The impact of bank regulations, supervision, market structure, and bank characteristics on individual bank ratings: A cross-country analysis. Review of Quantitative Finance and Accounting, 27, 403-438.

PASIOURAS, F., TANNA, S. \& ZOPOUNIDIS, C. 2009. The impact of banking regulations on banks' cost and profit efficiency: Cross-country evidence. International Review of Financial Analysis, 18, 294-302.

POGHOSYAN, T. \& ČIHÁK, M. 2009. Distress in European banks: An analysis based on a new dataset. IMF Working Papers, 1-37.

RADIĆ, N., FIORDELISI, F. \& GIRARDONE, C. 2012. Efficiency and risk-taking in precrisis investment banks. Journal of Financial Services Research, 41, 81-101.

REPULLO, R. 2004. Capital requirements, market power, and risk-taking in banking. Journal of financial Intermediation, 13, 156-182.

SANTOMERO, A. M. 1997. Deposit insurance: Do we need it and why? Ekonomia, 1(1), 119.

SCHAECK, K. \& CIHAK, M. 2012. Banking competition and capital ratios. European Financial Management, 18, 836-866.

SHLEIFER, A. 1998. State versus private ownership. National bureau of economic research.

SHLEIFER, A. \& VISHNY, R. W. 1994. Politicians and firms. The Quarterly Journal of Economics, 995-1025.

STIGLITZ, J. E. 1993. The role of the state in financial markets. The World Bank Economic Review, 7, 19-52.

TAN, Y. \& FLOROS, C. 2012. Bank profitability and inflation: the case of China. Journal of Economic Studies, 39, 675-696.

THANASSOULIS, E. 2001. Introduction to the theory and application of data envelopment analysis, Springer.

UHDE, A. \& HEIMESHOFF, U. 2009. Consolidation in banking and financial stability in Europe: Empirical evidence. Journal of Banking \& Finance, 33, 1299-1311.

VIVES, X. 2011. Competition and stability in banking. Central Banking, Analysis, and Economic Policies Book Series, 16, 455-502. 
WANKE, P., AZAD, M. A. K. \& BARROS, C. P. 2016. Financial distress and the Malaysian dual baking system: A dynamic slacks approach. Journal of Banking \& Finance, 66, $1-18$.

WANKE, P., BARROS, C. P. \& FARIA, J. R. 2015. Financial distress drivers in Brazilian banks: A dynamic slacks approach. European Journal of Operational Research, 240, 258-268.

WEN, S.-Y. \& YU, J. 2013. Banking stability, market structure and financial system in emerging countries. Journal of applied finance and Banking, 3, 1.

WINTON, A. 1995. Delegated monitoring and bank structure in a finite economy. Journal of Financial Intermediation, 4, 158-187. 
Table 1: Variables' definitions and sources of data

\begin{tabular}{|c|c|c|}
\hline Variables & Definitions & Sources \\
\hline \multicolumn{3}{|l|}{ Dependent variables: } \\
\hline $\begin{array}{l}\text { CAMELS } \\
\text { Inputs: } \\
\text { Asset quality } \\
\text { Management } \\
\text { Outputs: } \\
\text { Capital adequacy } \\
\text { Earnings quality } \\
\text { Liquidity } \\
\text { Sensitivity of market risk } \\
\text { (size) }\end{array}$ & $\begin{array}{l}\text { This combination is applied as a proxy of financial } \\
\text { stability, with two inputs and four outputs as follows: } \\
\begin{array}{ll}\text { Loan loss provision } & \text { (million/USD) } \\
\text { Total expenses } & \text { (million/USD) } \\
& \\
\text { Total equity } & \text { (million/USD) } \\
\text { Total net income } & \text { (million/USD) } \\
\text { Liquid assets } & \text { (million/USD) } \\
\text { Total assets } & \text { (million/USD) }\end{array}\end{array}$ & $\begin{array}{l}\text { Authors' estimation } \\
\text { based on Eq. (2) } \\
\text { BankScope } \\
\text { BankScope } \\
\text { BankScope } \\
\text { BankScope } \\
\text { BankScope } \\
\text { BankScope }\end{array}$ \\
\hline \multicolumn{3}{|l|}{ Independent variables: } \\
\hline $\begin{array}{l}\text { Core Profitability Model } \\
\frac{(C P M)}{\text { Inputs: }} \\
\text { Cost1 } \\
\text { Cost2 } \\
\text { Outputs: } \\
\text { Profit1 } \\
\text { Profit2 }\end{array}$ & $\begin{array}{l}\text { The CPM consists of two cost inputs and two profit } \\
\text { outputs as follows: } \\
\begin{array}{l}\text { Total interest expenses } \\
\text { Non-interest expenses }\end{array} \\
\begin{array}{l}\text { Gross interest dividend income (million/USD) } \\
\text { Non-interest operating income (million/USD) }\end{array} \\
\end{array}$ & $\begin{array}{l}\text { Authors' estimation } \\
\text { based on Eq. (2) } \\
\text { BankScope } \\
\text { BankScope } \\
\text { BankScope } \\
\text { BankScope }\end{array}$ \\
\hline Capital regulation index & $\begin{array}{l}\text { This index is used to determine whether the capital } \\
\text { requirement reflects certain risk elements and deducts } \\
\text { certain market value losses from capital before } \\
\text { minimum capital adequacy is determined. Further, } \\
\text { certain funds, official or otherwise, may initially be } \\
\text { used to capitalise a bank. The index has a range of } 0 \text { - } \\
10 \text {, with higher values indicating greater stringency. }\end{array}$ & $\begin{array}{l}\text { World Bank Survey } \\
\text { (Barth et al., 1999, } \\
\text { 2003, 2007, 2012) }\end{array}$ \\
\hline Capital regulation index & $\begin{array}{l}\text { This index is used to determine whether the capital } \\
\text { requirement reflects certain risk elements and deducts } \\
\text { certain market value losses from capital before } \\
\text { minimum capital adequacy is determined. Further, } \\
\text { certain funds, official or otherwise, may initially be } \\
\text { used to capitalise a bank. The index has a range of } 0 \text { - } \\
10 \text {, with higher values indicating greater stringency. }\end{array}$ & $\begin{array}{l}\text { World Bank Survey } \\
\text { (Barth et al., 1999, } \\
\text { 2003, 2007, 2012) }\end{array}$ \\
\hline $\begin{array}{l}\text { Activity } \\
\text { restrictions }\end{array}$ & $\begin{array}{l}\text { Overall restrictions on banking activities such as } \\
\text { securities, insurance, and property activities. The } \\
\text { restrictions have a range of } 0-12 \text {, with higher values } \\
\text { indicating greater restrictiveness. }\end{array}$ & $\begin{array}{l}\text { World Bank Survey } \\
\text { (Barth et al., 1999, } \\
\text { 2003, 2007, 2012) }\end{array}$ \\
\hline $\begin{array}{l}\text { Deposit } \\
\text { insurance }\end{array}$ & $\begin{array}{l}\text { This variable is used to determine whether a deposit } \\
\text { insurance authority has the power to make a decision to } \\
\text { intervene in a bank and take legal action against a } \\
\text { bank's directors or officials. The variable is also used } \\
\text { to establish whether a deposit insurance authority has } \\
\text { ever taken any legal action against bank directors or } \\
\text { officers. The range is } 0-4 \text {, with higher values } \\
\text { indicating greater power. }\end{array}$ & $\begin{array}{l}\text { World Bank Survey } \\
\text { (Barth et al., 1999, } \\
\text { 2003, 2007, 2012) }\end{array}$ \\
\hline
\end{tabular}




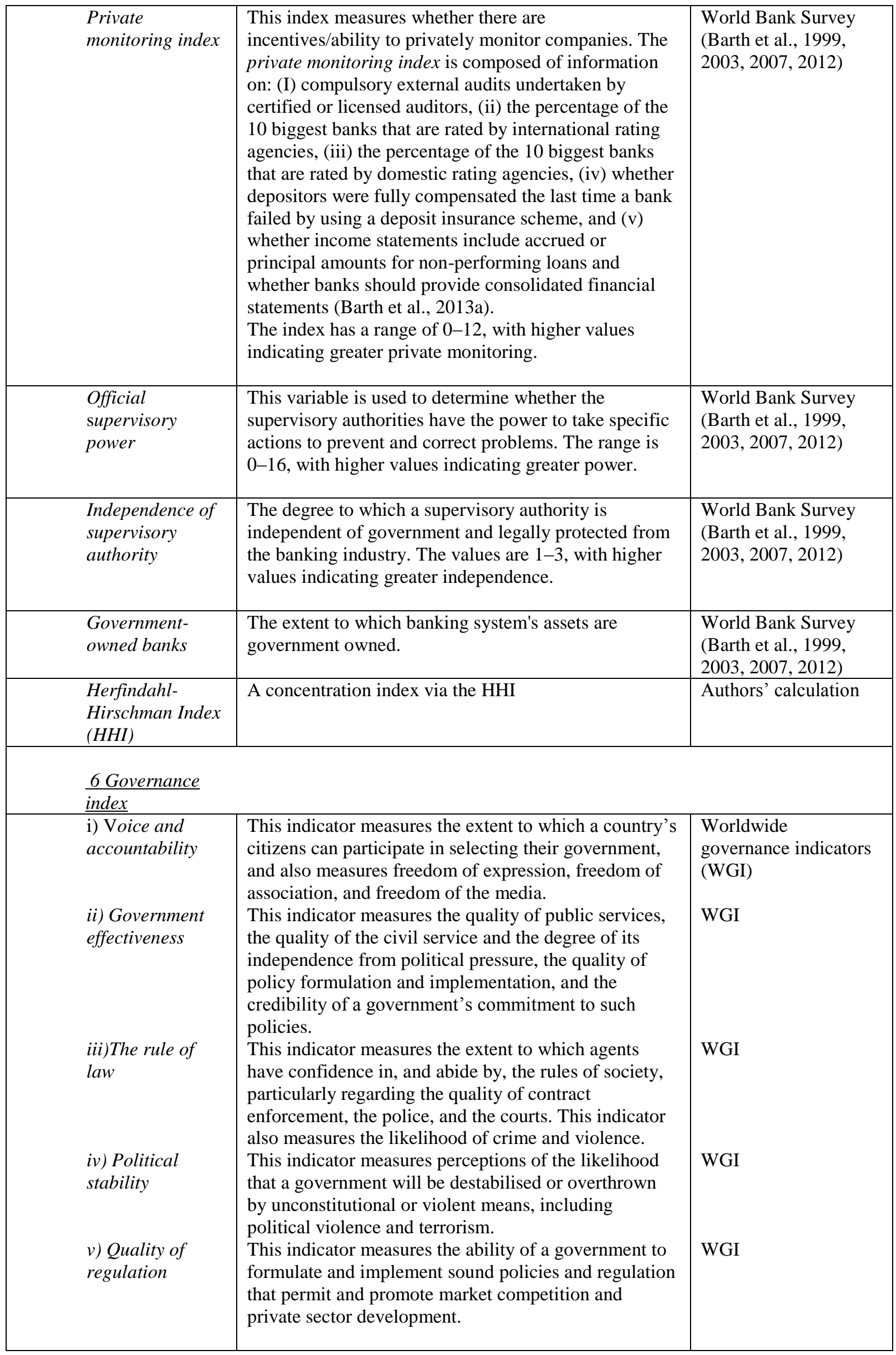




\begin{tabular}{|l|l|l|}
\hline $\begin{array}{l}\text { vi) Control of } \\
\text { corruption }\end{array}$ & $\begin{array}{l}\text { This indicator measures the extent to which public } \\
\text { power is exercised for private gain, including both } \\
\text { petty and grand forms of corruption, as well as the } \\
\text { capturing' of a state by an elite or private interests. }\end{array}$ & WGI \\
\hline $\begin{array}{l}\text { Business } \\
\text { (Economic) } \\
\text { freedom index }\end{array}$ & $\begin{array}{l}\text { This index relies on 10 factors grouped into four } \\
\text { categories: (1) the rule of law (property rights, freedom } \\
\text { from corruption); (2) limited government (fiscal } \\
\text { freedom, government spending); (3) regulatory } \\
\text { efficiency (business freedom, labour freedom, } \\
\text { monetary freedom); and (4) open markets (trade } \\
\text { freedom, investment freedom, and financial freedom). }\end{array}$ & Freedom \\
\hline $\begin{array}{l}\text { Log of gross } \\
\text { domestic product }\end{array}$ & The natural logarithm of GDP. & $\begin{array}{l}\text { World Development } \\
\text { Indicators (WDI) }\end{array}$ \\
\hline \begin{tabular}{l} 
Inflation \\
\hline
\end{tabular} & The annual change in the consumer price index. & WDI \\
\hline
\end{tabular}

Table 2: Summary Statistics

\begin{tabular}{llcccc}
\hline Variables & Obs & Mean & Std Dev. & Min. & Max. \\
\hline CAMELS (\%): Stability & 12444 & 52.33 & 23.85 & 16.6 & 100 \\
CPM (\%): Core Profitability Model & 12444 & 52.65 & 14.99 & 0 & 100 \\
Capital regulation index & 12444 & 6.39 & 1.66 & 2 & 10 \\
Activity restrictions & 12294 & 5.84 & 1.24 & 0 & 10 \\
Deposit Insurance & 12294 & 1.10 & 0.92 & 0 & 4 \\
Private monitoring index & 12294 & 7.74 & 1.41 & 0 & 11 \\
Official supervisory power & 12294 & 10.48 & 2.43 & 2 & 15.5 \\
Government-owned banks (\%) & 12267 & 17.68 & 17.71 & 0 & 75.2 \\
HHI & 12444 & 1801.50 & 1376.58 & 153.68 & 38261.89 \\
Governance index & 12411 & 69.89 & 26.06 & 14.13 & 108.98 \\
Business freedom index & 12302 & 65.01 & 9.83 & 36.6 & 82.6 \\
GDP (\%) & 11508 & 3.13 & 3.58 & -5.38 & 9.96 \\
Inflation (\%) & 11204 & 4.61 & 4.29 & -0.69 & 15.79 \\
\hline
\end{tabular}

Sample period: 2000-2016. See Table 1 for detailed definition. 
Table 3: Correlation matrix

\begin{tabular}{|c|c|c|c|c|c|c|c|c|c|c|c|c|c|}
\hline Variables & (1) & (2) & (3) & (4) & (5) & (6) & (7) & (8) & (9) & (10) & (11) & (12) & (13) \\
\hline CAMELS (1) & 1 & & & & & & & & & & & & \\
\hline$C P M(2)$ & 0.1872 & 1 & & & & & & & & & & & \\
\hline Capital regulation index (3) & 0.0139 & 0.0161 & 1 & & & & & & & & & & \\
\hline Activity restrictions (4) & -0.0745 & 0.0002 & -0.0326 & 1 & & & & & & & & & \\
\hline Deposit insurance (5) & -0.0631 & -0.0833 & 0.2593 & -0.0521 & 1 & & & & & & & & \\
\hline Private monitoring index (6) & 0.0749 & -0.011 & -0.065 & 0.0312 & -0.0792 & 1 & & & & & & & \\
\hline Government-owned banks (8) & -0.2247 & -0.0836 & 0.0687 & -0.0666 & 0.0238 & -0.1365 & -0.0309 & 1 & & & & & \\
\hline$H H I(9)$ & 0.1463 & 0.0956 & -0.093 & -0.0022 & -0.2261 & -0.0486 & 0.0056 & -0.2842 & 1 & & & & \\
\hline Governance index (10) & 0.3339 & 0.1673 & -0.08 & -0.1054 & -0.1309 & 0.153 & -0.0234 & -0.5998 & 0.3872 & 1 & & & \\
\hline Business freedom index (11) & 0.3412 & 0.1528 & -0.0455 & -0.1338 & -0.1367 & 0.2382 & 0.1132 & -0.5113 & 0.2921 & 0.8872 & 1 & & \\
\hline$G D P(12)$ & -0.1219 & -0.23 & 0.0316 & -0.031 & 0.0635 & -0.0068 & 0.0772 & 0.4711 & -0.1967 & -0.4057 & -0.333 & 1 & \\
\hline Inflation (13) & -0.1955 & -0.1128 & 0.1205 & -0.0276 & 0.0639 & -0.0924 & -0.0539 & 0.5752 & -0.1818 & -0.6303 & -0.5732 & 0.3969 & 1 \\
\hline
\end{tabular}

CPM: Core Profitability Model; HHI: Herfindal-Hirschman Index 
Table 4 Main model with dependant variable CAMELS (Bank stability)

\begin{tabular}{|c|c|c|c|c|c|c|}
\hline \multirow[b]{2}{*}{ Variables } & (1) & (2) & (3) & (4) & (5) & (6) \\
\hline & Q0.10 & Q0.25 & Q0.50 & Q0.75 & Q0.90 & OLS \\
\hline \multirow[t]{2}{*}{ Lagged CAMELS } & $0.267 * * *$ & $0.475 * * *$ & $0.825 * * *$ & $0.824 * * *$ & $0.622 * * *$ & $0.6083^{* * *}$ \\
\hline & $(0.0104)$ & $(0.0128)$ & $(0.0148)$ & $(0.00650)$ & $(0.0174)$ & $(0.0090)$ \\
\hline \multirow[t]{2}{*}{$C P M$} & $0.0199 * *$ & 0.0123 & $-0.0214^{*}$ & $0.0390 * * *$ & $0.134 * * *$ & $0.0307^{* *}$ \\
\hline & $(0.00907)$ & $(0.00975)$ & $(0.0120)$ & $(0.0140)$ & $(0.0315)$ & $(0.0140)$ \\
\hline \multirow[t]{2}{*}{ Capital regulation index } & $0.174 * *$ & $0.428 * * *$ & $0.686^{* * *}$ & $0.650 * * *$ & $0.955 * * *$ & $0.6029^{* * * *}$ \\
\hline & $(0.0755)$ & (0.0798) & $(0.0961)$ & (0.110) & $(0.290)$ & $(0.1108)$ \\
\hline \multirow[t]{2}{*}{ Activity restrictions } & $-0.201 *$ & -0.123 & $-0.219 *$ & $-0.584 * * *$ & $-0.867 * *$ & $-0.4658^{* * * *}$ \\
\hline & $(0.113)$ & $(0.107)$ & $(0.125)$ & $(0.142)$ & $(0.433)$ & $(0.1523)$ \\
\hline \multirow[t]{2}{*}{ Deposit insurance } & $-0.237^{*}$ & $-0.434 * * *$ & $-0.592 * * *$ & $-0.649 * * *$ & $-1.619 * * *$ & $-0.7275^{\text {**** }}$ \\
\hline & $(0.142)$ & $(0.154)$ & $(0.169)$ & $(0.205)$ & $(0.513)$ & $(0.1955)$ \\
\hline \multirow[t]{2}{*}{ Private monitoring index } & $-0.196 * *$ & $-0.296 * * *$ & $-0.339 * * *$ & $-0.563 * * *$ & $-0.671 *$ & 0.0517 \\
\hline & $(0.0845)$ & $(0.0844)$ & $(0.0890)$ & $(0.136)$ & $(0.389)$ & $(0.1274)$ \\
\hline \multirow[t]{2}{*}{ Official supervisory power } & -0.0461 & $-0.174 * * *$ & $-0.337 * * *$ & $-0.390 * * *$ & $-0.732 * * *$ & $-0.1588^{* *}$ \\
\hline & $(0.0513)$ & $(0.0504)$ & $(0.0614)$ & $(0.0854)$ & $(0.190)$ & $(0.0728)$ \\
\hline \multirow[t]{2}{*}{ Government-owned banks } & $-0.0273 * * *$ & $-0.0355 * * *$ & $-0.0438 * * *$ & $-0.0281 *$ & $-0.0673^{*}$ & $-0.0479^{* * *}$ \\
\hline & $(0.00897)$ & $(0.00849)$ & $(0.0111)$ & $(0.0160)$ & $(0.0381)$ & $(0.0131)$ \\
\hline \multirow[t]{2}{*}{$H H I$} & $0.000477 * * *$ & $0.000460^{* *}$ & $0.000353^{* *}$ & $0.000575 * * *$ & 0.000840 & $0.0004^{* *}$ \\
\hline & (0.000119) & (0.000187) & (0.000159) & (0.000152) & $(0.000555)$ & $(0.0002)$ \\
\hline \multirow[t]{2}{*}{ Business freedom index } & $0.161 * * *$ & $0.200 * * *$ & $0.222 * * *$ & $0.197 * * *$ & $0.462 * * *$ & $0.2914^{* * * *}$ \\
\hline & (0.0184) & $(0.0202)$ & $(0.0222)$ & $(0.0249)$ & $(0.0752)$ & $(0.0250)$ \\
\hline \multirow[t]{2}{*}{$G D P$} & $0.0862 * * *$ & $0.212 * * *$ & $0.266 * * *$ & $0.210 * * *$ & 0.192 & $0.2439^{* * *}$ \\
\hline & $(0.0298)$ & $(0.0328)$ & (0.0459) & $(0.0643)$ & (0.169) & $(0.0552)$ \\
\hline \multirow[t]{2}{*}{ Inflation } & $-0.0492 *$ & -0.0357 & -0.0514 & $-0.105 * * *$ & 0.229 & -0.0239 \\
\hline & $(0.0251)$ & $(0.0341)$ & $(0.0373)$ & $(0.0397)$ & $(0.150)$ & $(0.0414)$ \\
\hline \multirow[t]{2}{*}{ Constant } & $9.925 * * *$ & $3.991 * *$ & -1.603 & $9.849 * * *$ & $16.21 * *$ & 0.6939 \\
\hline & (1.633) & (1.559) & (1.909) & $(2.401)$ & $(7.205)$ & $(2.2333)$ \\
\hline Country dummy & Yes & Yes & Yes & Yes & Yes & Yes \\
\hline Time dummy & Yes & Yes & Yes & Yes & Yes & Yes \\
\hline $\begin{array}{l}\text { Observations } \\
R^{2}\end{array}$ & 10,998 & 10,998 & 10,998 & 10,998 & 10,998 & $\begin{array}{l}10,998 \\
0.452\end{array}$ \\
\hline
\end{tabular}

CPM: Core Profitability Model; HHI: Herfindal-Hirschman Index.

This table presents the QR estimates for our main sample. The dependent variable is bank stability based on CAMELS-DEA. The quantiles are reported from columns 1 to 5. Bootstrapped standard errors are based on 1000 replications and are reported in parentheses. $* * *$ represents $\mathrm{p}<0.01, * *$ represents $\mathrm{p}<0.05$ and $*$ represents $\mathrm{p}<0.1$ across all quantiles. OLS regression is reported in column 6 with heteroscedasticity-robust standard errors for OLS. $\pm \mathrm{F}$ tests for the equality of the slope coefficient across various quantiles have been undertaken and are significant at the 5\% level for most quantiles; however, they are not reported in order to save space. The details are available upon request from the authors. 
Table 5a Banks' business models and financial stability

\begin{tabular}{|c|c|c|c|c|c|c|c|c|c|c|c|c|}
\hline $\begin{array}{l}\frac{0}{0} \\
\frac{\pi}{\pi} \\
>\end{array}$ & 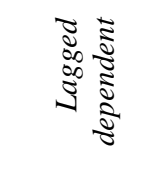 & $\underset{\delta}{\Sigma}$ & 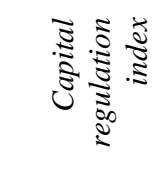 & 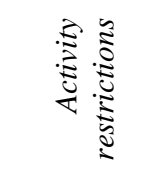 & 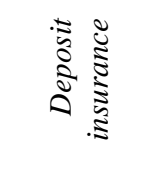 & 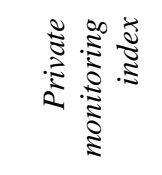 & 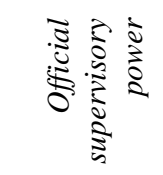 & 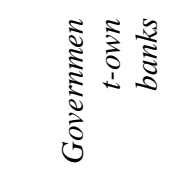 & $\underset{\mathbb{Z}}{\mathbb{Z}}$ & 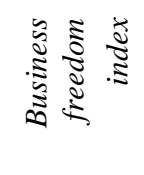 & ิิ & 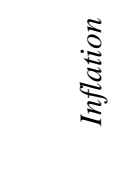 \\
\hline \multicolumn{13}{|c|}{ Commercial banks (1747 banks) } \\
\hline $\mathrm{Q} 0.10$ & $0.257 * * *$ & $0.0197 *$ & $0.210 * * *$ & -0.194 & -0.252 & $-0.169 *$ & -0.0546 & $-0.0180 *$ & $0.000490 * * *$ & $0.170 * * *$ & $0.0619 * *$ & $-0.0526 * *$ \\
\hline Q0.25 & $0.454 * * *$ & $0.0221 * *$ & $0.487 * * *$ & -0.0604 & $-0.376^{* *}$ & $-0.309 * * *$ & $-0.185 * * *$ & $-0.0226 * *$ & $0.000671 * * *$ & $0.201 * * *$ & $0.241 * * *$ & $-0.0640 *$ \\
\hline Q0.50 & $0.789 * * *$ & -0.00517 & $0.806^{* * *}$ & -0.0974 & $-0.570^{* * *}$ & $-0.392 * * *$ & $-0.352 * * *$ & $-0.0350 * * *$ & $0.000443 * * *$ & $0.247 * * *$ & $0.339 * * *$ & -0.056 \\
\hline Q0.75 & $0.826 * * *$ & $0.0441 * * *$ & $0.754 * * *$ & $-0.518 * * *$ & $-0.669 * * *$ & $-0.623 * * *$ & $-0.410 * * *$ & -0.0169 & $0.000562 * * *$ & $0.221 * * *$ & $0.241 * * *$ & $-0.0985 * *$ \\
\hline Q0.90 & $0.661 * * *$ & $0.132 * * *$ & $1.063 * * *$ & $-0.710^{*}$ & $-1.524 * * *$ & $-0.768 * *$ & $-0.817 * * *$ & -0.0344 & 0.000554 & $0.535^{* * *}$ & $0.307 *$ & $0.267^{*}$ \\
\hline OLS & $0.602 * * *$ & $0.0368 * *$ & $0.695 * * *$ & $-0.252 *$ & $-0.600 * * *$ & $-0.224 *$ & $-0.379 * * *$ & $-0.0325 * *$ & $0.000422^{* *}$ & $0.323^{* * *}$ & $0.317 * * *$ & -0.0491 \\
\hline \multicolumn{13}{|c|}{ Investment banks (269 banks) } \\
\hline $\mathrm{Q} 0.10$ & $0.191 * * *$ & $0.0453 * *$ & $0.286^{* *}$ & 0.736 & 0.197 & $-0.913^{*}$ & -0.209 & $-0.0627 * *$ & 0.000456 & 0.103 & $0.193 * *$ & -0.00711 \\
\hline Q0.25 & $0.392 * * *$ & 0.0434 & -0.155 & 0.785 & 0.0316 & -0.700 & -0.332 & $-0.0949 * *$ & -0.00053 & 0.0952 & $0.240^{* *}$ & -0.0869 \\
\hline Q0.50 & $0.782 * * *$ & -0.0425 & $0.0631 *$ & 1.035 & $-1.526^{*}$ & -0.801 & -0.18 & $-0.0958 *$ & 0.000117 & 0.085 & -0.0253 & -0.0733 \\
\hline Q0.75 & $0.754 * * *$ & 0.046 & -0.714 & -0.634 & -1.609 & -0.293 & 0.583 & $-0.270 * * *$ & 0.000626 & -0.126 & -0.113 & -0.00522 \\
\hline Q0.90 & $0.563 * * *$ & 0.088 & -0.145 & -1.56 & $-1.467 *$ & 2.174 & 1.255 & $-0.348 *$ & 0.0022 & $-0.936 * *$ & -0.923 & -0.482 \\
\hline OLS & $0.534 * * *$ & 0.0397 & -0.496 & 0.138 & $-1.757^{*}$ & 0.224 & 0.264 & $-0.189 * * *$ & $6.52 \mathrm{E}-05$ & -0.0984 & -0.121 & 0.00189 \\
\hline \multicolumn{13}{|c|}{ Bank holding companies (194 banks) } \\
\hline $\mathrm{Q} 0.10$ & $0.493 * * *$ & -0.00847 & -0.409 & -2.377 & -1.12 & -0.74 & -0.558 & -0.137 & 0.000548 & 0.384 & -0.3 & 0.171 \\
\hline Q0.25 & $0.780 * * *$ & 0.043 & 0.0779 & $-2.412 *$ & -0.298 & -0.0442 & -0.492 & $-0.128 *$ & 0.000841 & 0.091 & 0.533 & -0.186 \\
\hline Q0.50 & $0.895^{* * *}$ & 0.01 & $0.121 * *$ & $-0.420 * *$ & 0.572 & 0.157 & -0.256 & $-0.0364 *$ & 0.000531 & 0.0453 & 0.234 & $-0.265^{*}$ \\
\hline Q0.75 & $0.652 * * *$ & 0.0453 & 0.209 & $-2.494 *$ & 0.996 & -0.107 & -0.68 & -0.0703 & $0.00228 * *$ & 0.0492 & 0.371 & -0.364 \\
\hline Q0.90 & 0.000 & -0.002 & 0.008 & -0.000 & 0.000 & -0.012 & -0.000 & -0.000 & 0.005 & -0.000 & 0.000 & -0.000 \\
\hline OLS & $0.580 * * *$ & 0.0507 & 0.762 & $-3.906 * * *$ & 0.537 & -0.201 & -0.501 & $-0.154 * *$ & $0.00182^{* * * *}$ & 0.0656 & $0.650 * *$ & $-0.425^{* * *}$ \\
\hline
\end{tabular}

CPM: Core Profitability Model; HHI: Herfindal-Hirschman Index

This table presents the QR estimates based on banks' business models. Country and time dummies are specified in respective regressions. The dependent variable is bank stability based on CAMELS-DEA. The quantiles at Q0.10, Q0.25, Q0.50, Q0.75, and Q0.90 for each bank business model are reported in the above table. Bootstrapped standard errors are based on 1000 replications, though not reported to save space. $* * *$ represents $p<0.01 * *$ represents $\mathrm{p}<0.05$, and $*$ represents $\mathrm{p}<0.1$ across all quantiles. OLS regression is reported for each business model, and heteroskedasticity-robust standard errors are applied for OLS. \pm F tests for the equality of the slope coefficient across various quantiles have been undertaken and are significant at the 5\% level for most quantiles; however, they are not reported in order to save space. The details are available upon request. A number of observations: Commercial banks 9,789 banks; Investment banks 624 banks; bank holding companies 585 banks. 


\begin{tabular}{|c|c|c|c|c|c|c|c|c|c|c|c|c|}
\hline \multirow[b]{3}{*}{ Variables } & \multirow{2}{*}{$\begin{array}{c}\text { Listed } \\
\text { Banks } \\
(1) \\
\end{array}$} & \multicolumn{11}{|c|}{ Unlisted } \\
\hline & & $(2)$ & (3) & $(4)$ & $(5)$ & (6) & $(7)$ & $(8)$ & $(9)$ & $(10)$ & $(11)$ & (12) \\
\hline & Q0.10 & Q0.25 & Q0.50 & Q0.75 & Q0.90 & OLS & $\mathrm{Q} 0.10$ & Q0.25 & Q0.50 & Q0.75 & Q0.90 & OLS \\
\hline Lagged dependent & $0.377 * * *$ & $0.666^{* * * *}$ & $0.913 * * *$ & $0.826 * * *$ & $0.620 * * *$ & $0.690 * * *$ & $0.228 * * *$ & $0.410 * * *$ & $0.710 * * *$ & $0.808 * * *$ & $0.641 * * *$ & $0.557 * * *$ \\
\hline$C P M$ & 0.00741 & -0.0218 & -0.00338 & $0.0541 * *$ & $0.170 * * *$ & $0.0342 *$ & $0.0251 * *$ & 0.0175 & -0.0113 & $0.0463 * *$ & $0.0955^{* *}$ & $0.0411 * *$ \\
\hline Capital regulation index & $0.328^{*}$ & $0.682 * * *$ & $0.336^{* *}$ & $0.402 * *$ & 0.399 & $0.735 * * *$ & 0.113 & $0.360 * * *$ & $0.583 * * *$ & $0.748 * * *$ & $1.057 * * *$ & $0.510 * * *$ \\
\hline Activity restrictions & -0.211 & $-0.0313 *$ & $-0.00198 * *$ & 0.547 & -0.180 & -0.173 & $-0.425 * * *$ & -0.0703 & 0.00538 & -0.254 & 0.332 & -0.0659 \\
\hline Deposit insurance & -0.318 & $-0.857 * * *$ & -0.0570 & -0.401 & $-1.315^{* *}$ & $-0.627 *$ & -0.0696 & $-0.354 * *$ & $-0.704 * * *$ & $-0.702 * * *$ & $-2.139 * * *$ & $-0.842 * * *$ \\
\hline $\begin{array}{l}\text { Private monitoring } \\
\text { index }\end{array}$ & -0.157 & $-0.392 *$ & $-0.378 * * *$ & $-0.549 * *$ & 0.183 & -0.183 & -0.106 & $-0.376^{* * *}$ & $-0.796 * * *$ & $-0.826 * * *$ & $-1.554 * * *$ & $-0.593 * * *$ \\
\hline $\begin{array}{l}\text { Official supervisory } \\
\text { power }\end{array}$ & $-0.298 * *$ & $-0.270 * *$ & $-0.376 * * *$ & $-0.281^{*}$ & $-0.592 * *$ & $-0.422 * * *$ & 0.0179 & $-0.108^{*}$ & $-0.163 * *$ & $-0.373 * * *$ & $-0.789 * * *$ & $-0.228 * * *$ \\
\hline $\begin{array}{l}\text { Government-owned } \\
\text { banks }\end{array}$ & $-0.0437 * *$ & -0.0309 & $-0.0161^{*}$ & 0.0207 & 0.0576 & -0.00812 & -0.0147 & $-0.0279 * *$ & $-0.0531 * * *$ & $-0.0398 * *$ & -0.0588 & $-0.0443 * * *$ \\
\hline $\mathrm{HHI}$ & -0.00032 & -0.000491 & 0.00098 & $0.00065 * *$ & $0.000422 *$ & -0.000246 & $0.000535^{* * *}$ & $0.000434 * *$ & 0.000135 & 0.000675 & $0.000626^{*}$ & 0.00087 \\
\hline Business freedom index & $0.153 * * *$ & $0.219 * * *$ & $0.219 * * *$ & $0.252 * * *$ & $0.543 * * *$ & $0.397 * * *$ & $0.153^{* * *}$ & $0.197 * * *$ & $0.248 * * *$ & $0.267 * * *$ & $0.536 * * *$ & $0.324 * * *$ \\
\hline$G D P$ & $0.154 * *$ & $0.240 * * *$ & $0.218 * * *$ & 0.152 & $0.535^{*}$ & $0.345^{* * *}$ & $0.0634 *$ & $0.202 * * *$ & $0.291 * * *$ & $0.257 * * *$ & -0.0605 & $0.251 * * *$ \\
\hline Inflation & -0.0291 & -0.0827 & -0.0585 & -0.00945 & 0.0735 & -0.0298 & $-0.104 * * *$ & $-0.0995 *$ & $-0.0735^{*}$ & -0.0853 & 0.165 & -0.0692 \\
\hline Constant & $10.18 * * *$ & -0.128 & -3.555 & -0.296 & 0.0207 & -6.316 & $11.57 * * *$ & $6.246 * * *$ & 2.136 & $5.612 *$ & $15.78 * *$ & $4.878^{*}$ \\
\hline Country dummy & Yes & Yes & Yes & Yes & Yes & Yes & Yes & Yes & Yes & Yes & Yes & Yes \\
\hline Time dummy & Yes & Yes & Yes & Yes & Yes & Yes & Yes & Yes & Yes & Yes & Yes & Yes \\
\hline Observations & 3,097 & 3,097 & 3,097 & 3,097 & 3,097 & 3,097 & 7,915 & 7,915 & 7,915 & 7,915 & 7,915 & 7,915 \\
\hline banks & 467 & 467 & 467 & 467 & 467 & 467 & 1743 & 1743 & 1743 & 1743 & 1743 & 1743 \\
\hline R-squared & & & & & & 0.561 & & & & & & 0.398 \\
\hline
\end{tabular}

CPM: Core Profitability Model; HHI: Herfindal-Hirschman Index

This table presents the QR estimates based on listed and unlisted. The dependent variable is bank stability based on CAMELS-DEA. The quantiles are reported in columns 1 to 5 and 7 to 11 . Bootstrapped standard errors are based on 1000 replications, though not reported to save space. $* * *$ represents $\mathrm{p}<0.01$, $* *$ represents $\mathrm{p}<0.05$, and $*$ represents $\mathrm{p}<0.1$ across all quantiles. OLS regression is reported in columns 6 and 12 with heteroscedasticity-robust standard errors for OLS. The quantiles at Q0.10, Q0.25,

Q0.50, Q0.75 and Q0.90 are applied across listed banks and unlisted banks. $\pm \mathrm{F}$ tests for the equality of the slope coefficient across various quantiles have been undertaken and are significant at the $5 \%$ level for most quantiles; however, they are not reported in order to save space. The details are available upon request 


\begin{tabular}{|c|c|c|c|c|c|c|c|c|c|c|c|c|}
\hline \multirow[b]{3}{*}{ Variables } & \multicolumn{6}{|l|}{$\frac{\text { Large }}{\underline{\text { Banks }}}$} & \multicolumn{6}{|l|}{$\underline{\underline{\text { Small }}}$} \\
\hline & (1) & (2) & (3) & (4) & (5) & (6) & $\overline{(7)}$ & (8) & (9) & (10) & (11) & (12) \\
\hline & Q0.10 & Q0.25 & Q0.50 & Q0.75 & Q0.90 & OLS & Q0.10 & Q0.25 & Q0.50 & Q0.75 & Q0.90 & OLS \\
\hline Lagged dependent & $0.386 * * *$ & $0.648 * * *$ & $0.916 * * *$ & $0.806^{* * *}$ & $0.477 * * *$ & $0.669 * * *$ & $0.139 * * *$ & $0.247 * * *$ & $0.431 * * *$ & $0.667 * * *$ & $0.684 * * *$ & $0.385 * * *$ \\
\hline$C P M$ & $0.0389 * *$ & -0.0174 & 0.00901 & $0.0557 * *$ & $0.115 * * *$ & $0.0581 * * *$ & $0.0236 * *$ & $0.0239 *$ & $0.0453 * * *$ & 0.0403 & $0.0810 *$ & $0.0490 * * *$ \\
\hline $\begin{array}{l}\text { Capital regulation } \\
\text { index }\end{array}$ & $0.472 * * *$ & $0.475^{* * *}$ & $0.384 * * *$ & 0.158 & 0.52 & $0.509 * * *$ & -0.000484 & 0.151 & $0.462 * * *$ & $1.178 * * *$ & $2.069 * * *$ & $0.563 * * *$ \\
\hline Activity restrictions & 0.194 & -0.131 & -0.0842 & -0.236 & $-1.333 * * *$ & $-0.373 *$ & $-0.617 * * *$ & $-0.884 * * *$ & $-1.113 * * *$ & $-1.628 * * *$ & $-2.254 * * *$ & $-1.377 * * *$ \\
\hline Deposit insurance & $-0.493 * * *$ & $-0.730 * * *$ & $-0.421^{* *}$ & $-0.542 * *$ & $-1.467 * *$ & $-0.949 * * *$ & $-0.401 *$ & 0.139 & -0.199 & $-0.854 * *$ & $-2.160^{*}$ & $-0.648 * *$ \\
\hline $\begin{array}{l}\text { Private monitoring } \\
\text { index }\end{array}$ & 0.00113 & 0.0455 & -0.0741 & -0.132 & 0.28 & 0.0955 & $-0.333 * *$ & $-0.494 * *$ & $-0.725^{* * *}$ & $-1.382 * * *$ & $-1.597 * * *$ & $-0.647 * * *$ \\
\hline $\begin{array}{l}\text { Official supervisory } \\
\text { power }\end{array}$ & -0.077 & -0.0871 & -0.0993 & -0.0434 & -0.254 & -0.155 & $0.0886^{*}$ & -0.0288 & $-0.174 * *$ & $-0.174 * *$ & $-0.783 * * *$ & $-0.105^{*}$ \\
\hline $\begin{array}{l}\text { Government-owned } \\
\text { banks }\end{array}$ & -0.024 & -0.0205 & $-0.0234 *$ & -0.00736 & $-0.0914 *$ & -0.0307 & -0.0183 & $-0.0344 * * *$ & $-0.0578 * * *$ & $-0.0722 * *$ & -0.0677 & $-0.056 * * *$ \\
\hline HHI & $0.00032 * *$ & 0.00023 & $0.00032 * *$ & $0.00055^{* * *}$ & 0.00054 & $0.00052 * *$ & $0.00041 * *$ & $0.00087 * * *$ & $0.00099 * * *$ & $0.00073 * *$ & 0.0011 & $0.00065^{* *}$ \\
\hline Business freedom index & $0.0979 * * *$ & $0.135 * * *$ & $0.161 * * *$ & $0.144 * * *$ & $0.285 * * *$ & $0.290 * * *$ & $0.160 * * *$ & $0.212 * * *$ & $0.252 * * *$ & $0.252 * * *$ & $0.266 * * *$ & $0.287 * * *$ \\
\hline$G D P$ & $0.166^{* * *}$ & $0.258 * * *$ & $0.237 * * *$ & $0.286 * * *$ & $0.517 * *$ & $0.419 * * *$ & 0.0611 & $0.237 * * *$ & $0.378 * * *$ & $0.497 * * *$ & 0.361 & $0.366 * * *$ \\
\hline Inflation & 0.00833 & -0.0749 & -0.0457 & -0.0779 & 0.275 & 0.0354 & -0.00394 & -0.0281 & -0.00281 & -0.0664 & 0.0381 & -0.0134 \\
\hline Constant & 4.183 & 0.748 & $-5.676 * *$ & $8.201 * *$ & $35.91 * * *$ & -2.457 & $16.82 * * *$ & $14.85 * * *$ & $12.56 * * *$ & $17.20 * * *$ & $32.96 * * *$ & $16.54 * * *$ \\
\hline Country dummy & Yes & Yes & Yes & Yes & Yes & Yes & Yes & Yes & Yes & Yes & Yes & Yes \\
\hline Time dummy & Yes & Yes & Yes & Yes & Yes & Yes & Yes & Yes & Yes & Yes & Yes & Yes \\
\hline Observations & 5,590 & 5,590 & 5,590 & 5,590 & 5,590 & 5,590 & 5,408 & 5,408 & 5,408 & 5,408 & 5,408 & 5,408 \\
\hline banks & 1126 & 1126 & 1126 & 1126 & 1126 & 1126 & 1084 & 1084 & 1084 & 1084 & 1084 & 1084 \\
\hline$R$-squared & & & & & & 0.50 & & & & & & 0.28 \\
\hline
\end{tabular}

CPM: Core Profitability Model; HHI: Herfindal-Hirschman Index

This table presents the QR estimates based on bank size. The dependent variable is bank stability based on CAMELS-DEA. The quantiles are reported in columns 1 to 5 and 7 to 11 . Bootstrapped standard errors are based on 1000 replications, though not reported to save space. $* * *$ represents $\mathrm{p}<0.01$, $* *$ represents $\mathrm{p}<0.05$, and $*$ represents $\mathrm{p}<0.1$ across all quantiles. OLS regression is reported in columns 6 and 12 with heteroscedasticity-robust standard errors for OLS. The quantiles at Q0.10, Q0.25, Q0.50, Q0.75 and Q0.90 are applied across large banks and small banks. \pm F tests for the equality of the slope coefficient across various quantiles have been undertaken and are significant at the $5 \%$ level for most quantiles; however, they are not reported in order to save space. The details are available upon request. The sample is re-grouped into large and small banks based on a median point of total assets USD 1212.011 million. 
Table 7 Economic development and financial stability

\begin{tabular}{|c|c|c|c|c|c|c|c|c|c|c|c|c|}
\hline \multirow[b]{3}{*}{ Variables } & \multicolumn{6}{|l|}{ Emerging } & \multicolumn{6}{|l|}{ Advanced } \\
\hline & (1) & (2) & (3) & (4) & (5) & (6) & (7) & (8) & (9) & (10) & (11) & (12) \\
\hline & Q0.10 & Q0.25 & Q0.50 & Q0.75 & Q0.90 & OLS & Q0.10 & Q0.25 & Q0.50 & Q0.75 & Q0.90 & OLS \\
\hline Lagged dependent & $0.194 * * *$ & $0.321^{* * *}$ & $0.518 * * *$ & $0.791 * * *$ & $0.784 * * *$ & $0.508 * * *$ & $0.305 * * *$ & $0.575^{* * *}$ & $0.899 * * *$ & $0.823^{* * *}$ & $0.520 * * *$ & $0.643 * * *$ \\
\hline$C P M$ & 0.0137 & $0.0589 * * *$ & $0.0876 * * *$ & $0.0845^{* * *}$ & $0.103 *$ & $0.0755^{* * *}$ & 0.0204 & -0.00793 & -0.0254 & $0.0154 *$ & $0.0974 * * *$ & 0.0144 \\
\hline $\begin{array}{l}\text { Capital regulation } \\
\text { index }\end{array}$ & 0.0272 & $0.254 * *$ & $0.602 * * *$ & $1.061 * * *$ & $1.870 * * *$ & $0.635^{* * *}$ & $0.257 * *$ & $0.249 * *$ & $0.436 * * *$ & 0.0965 & 0.33 & $0.335 * *$ \\
\hline Activity restrictions & 0.0645 & -0.00338 & -0.0363 & -0.301 & 0.0275 & -0.256 & -0.158 & -0.0745 & 0.0792 & $-0.332 * *$ & $-0.954 * *$ & -0.248 \\
\hline Deposit insurance & -0.198 & $-0.472 * *$ & $-0.712 * * *$ & $-0.880 * *$ & $-1.985^{* * *}$ & $-1.053^{* * *}$ & -0.162 & $-0.510 * *$ & $-0.876^{* * *}$ & $-0.624 * *$ & $-1.575^{* * *}$ & $-0.934 * * *$ \\
\hline $\begin{array}{l}\text { Private monitoring } \\
\text { index }\end{array}$ & $-0.448 * * *$ & $-0.561 * * *$ & $-0.570^{* * *}$ & $-0.745^{* *}$ & $-1.544^{* *}$ & $-0.771 * * *$ & 0.277 & $0.461 * * *$ & $0.492 * * *$ & $0.146^{* *}$ & $0.84 *$ & $0.818^{* * *}$ \\
\hline $\begin{array}{l}\text { Official supervisory } \\
\text { power }\end{array}$ & -0.0479 & $-0.245^{* * *}$ & $-0.598 * * *$ & $-0.953 * * *$ & $-1.452 * * *$ & $-0.477 * * *$ & 0.0179 & $0.115^{* *}$ & $0.179 *$ & $0.241 * * *$ & 0.162 & $0.178 * *$ \\
\hline $\begin{array}{l}\text { Government-owned } \\
\text { banks }\end{array}$ & 0.00433 & 0.00154 & 0.012 & $0.0511 *$ & 0.0795 & $0.0432 * *$ & $-0.0463 * * *$ & $-0.0592 * * *$ & $-0.099 * * *$ & $-0.0415 * *$ & $-0.171 * * *$ & $-0.118 * * *$ \\
\hline$H H I$ & $0.00033 * *$ & 0.000176 & 0.00049 & $0.000761^{*}$ & $0.00198 * *$ & 0.000184 & $0.00080^{* * * *}$ & $0.00083^{* * *}$ & $0.00035^{* *}$ & $0.00046^{* *}$ & 0.000577 & $0.00058 * *$ \\
\hline $\begin{array}{l}\text { Business freedom } \\
\text { index }\end{array}$ & $0.209 * * *$ & $0.324 * * *$ & $0.484 * * *$ & $0.496 * * *$ & $0.669 * * *$ & $0.513 * * *$ & $0.120 * * *$ & $0.0692 *$ & $0.101 * *$ & $0.103 * * *$ & 0.15 & $0.162 * * *$ \\
\hline$G D P$ & 0.0327 & $0.235^{* * *}$ & $0.406 * * *$ & $0.432 * * *$ & $0.502 * *$ & $0.298 * * *$ & $0.345^{* * *}$ & $0.439 * * *$ & $0.534 * * *$ & $0.258 * * *$ & $0.733 * * *$ & $0.643 * * *$ \\
\hline Inflation & -0.0169 & -0.0267 & -0.0337 & -0.00684 & $0.318 * *$ & 0.00166 & $-0.270 * *$ & $-0.224 * *$ & $-0.236^{* * *}$ & $-0.199 * * *$ & $-0.304 *$ & $-0.253 * * *$ \\
\hline Constant & $10.80 * * *$ & 2.841 & $-8.611 * * *$ & $-8.806^{*}$ & -6.541 & -4.245 & 5.643 & 1.473 & $-7.355 * *$ & $8.207 * *$ & $33.35^{* * *}$ & 0.421 \\
\hline Country dummy & Yes & Yes & Yes & Yes & Yes & Yes & Yes & Yes & Yes & Yes & Yes & Yes \\
\hline Time dummy & Yes & Yes & Yes & Yes & Yes & Yes & Yes & Yes & Yes & Yes & Yes & Yes \\
\hline Observations & 4,666 & 4,666 & 4,666 & 4,666 & 4,666 & 4,666 & 6,332 & 6,332 & 6,332 & 6,332 & 6,332 & 6,332 \\
\hline banks & 1141 & 1141 & 1141 & 1141 & 1141 & 1141 & 1069 & 1069 & 1069 & 1069 & 1069 & 1069 \\
\hline Countries & 27 & 27 & 27 & 27 & 27 & 27 & 20 & 20 & 20 & 20 & 20 & 20 \\
\hline$R$-squared & & & & & & 0.344 & & & & & & 0.445 \\
\hline
\end{tabular}

CPM: Core Profitability Model; HHI: Herfindal-Hirschman Index

This table presents the QR estimates based on economic development. The dependent variable is bank stability based on CAMELS-DEA. The quantiles are reported in columns 1 to 5 and from 7 to 11 , Bootstrapped standard errors are based on 1000 replications, though not reported to save space. $* * *$ represents $\mathrm{p}<0.01$, ** represents $\mathrm{p}<0.05$, and $*$ represents $\mathrm{p}<0.1$ across all quantiles. OLS regression is reported in columns 6 and 12 with heteroscedasticity-robust standard errors for OLS. The quantiles at Q0.10, Q0.25, Q0.50, Q0.75 and Q0.90 are applied across emerging economies and advanced economies. $\pm \mathrm{F}$ tests for the equality of the slope coefficient across various quantiles have been undertaken and are significant at the $5 \%$ level for most quantiles; however, they are not reported in order to save space. The details are available upon request. 
Table 8 Governance and stability

\begin{tabular}{|c|c|c|c|c|c|c|}
\hline & $(1)$ & $(2)$ & (3) & (4) & $(5)$ & $(6)$ \\
\hline Variables & Q0.10 & Q0.25 & Q0.50 & Q0.75 & Q0.90 & OLS \\
\hline Lagged dependent & $0.263 * * *$ & $0.479 * * *$ & $0.832 * * *$ & $0.824 * * *$ & $0.619 * * *$ & $0.613 * * *$ \\
\hline$C P M$ & $0.0219 * *$ & 0.0137 & -0.0194 & $0.0389 * * *$ & $0.131 * * *$ & $0.0280 * *$ \\
\hline Capital regulation index & $0.213 * * *$ & $0.480 * * *$ & $0.688 * * *$ & $0.540 * * *$ & $1.047 * * *$ & $0.663 * * *$ \\
\hline Activity restrictions & $-0.224 *$ & -0.145 & -0.24 & $-0.556^{* * * *}$ & $-0.872 * *$ & $-0.504 * * *$ \\
\hline Deposit insurance & $-0.350 * *$ & $-0.502 * * *$ & $-0.676^{* * *}$ & $-0.768 * * *$ & $-1.860 * * *$ & $-0.846^{* * *}$ \\
\hline Private monitoring index & -0.107 & $-0.195 * *$ & $-0.256 * * *$ & $-0.432 * * *$ & -0.533 & 0.00406 \\
\hline $\begin{array}{l}\text { Official supervisory } \\
\text { power }\end{array}$ & 0.025 & -0.0777 & $-0.199 * * *$ & $-0.242 * * *$ & $-0.485^{* * *}$ & $-0.200 * * *$ \\
\hline Government-owned banks & $-0.0291 * * *$ & $-0.0296 * * *$ & $-0.0419 * * *$ & -0.0238 & -0.015 & $-0.0403 * * *$ \\
\hline$H H I$ & $0.000378 * * *$ & $0.000485 * *$ & $0.000295 *$ & $0.00045 * * *$ & 0.000342 & 0.000242 \\
\hline Governance index & $0.0556^{* * *}$ & $0.0614 * * *$ & $0.0659 * * *$ & $0.0686^{* * *}$ & $0.215^{* * *}$ & $0.107 * * *$ \\
\hline$G D P$ & $0.103 * * *$ & $0.206 * * *$ & $0.273 * * *$ & $0.162 * *$ & $0.315^{*}$ & $0.274 * * *$ \\
\hline Inflation & -0.04 & -0.0605 & -0.064 & -0.0687 & $0.250^{*}$ & -0.0328 \\
\hline Constant & $15.20 * * *$ & $10.44 * * *$ & $5.996 * * *$ & $16.01 * * *$ & $26.98 * * *$ & $12.96 * * *$ \\
\hline Country dummy & Yes & Yes & Yes & Yes & Yes & Yes \\
\hline Time dummy & Yes & Yes & Yes & Yes & Yes & Yes \\
\hline Observations & 11,014 & 11,014 & 11,014 & 11,014 & 11,014 & 11,014 \\
\hline$R$-squared & & & & & & 0.451 \\
\hline
\end{tabular}

CPM: Core Profitability Model; HHI: Herfindal-Hirschman Index

The dependent variable is bank stability based on CAMELS-DEA. The quantiles of governance and stability are reported in columns 1 to 5 . Bootstrapped standard errors are based on 1000 replications, though not reported here to save space.

represents $\mathrm{p}<0.01, * *$ represents $\mathrm{p}<0.05$, and $*$ represents $\mathrm{p}<0.1$ across all quantiles. OLS regression is reported in columns 6 with heteroskedasticity-robust standard errors for OLS. The quantiles at Q0.10, Q0.25, Q0.50, Q0.75 and Q0.90 are applied for governance and stability estimates. $\pm \mathrm{F}$ tests for the equality of the slope coefficient across various quantiles have been undertaken and are significant at the 5\% level for most quantiles; however, they are not reported in order to save space. The details are available upon request. 
Table 9 Quantile Fitted Value and GMM

\begin{tabular}{|c|c|c|c|c|c|c|}
\hline & $(1)$ & (2) & (3) & (4) & $(5)$ & $(6)$ \\
\hline Variables & Q0.10 & $\mathrm{Q} 0.25$ & Q0.50 & Q0.75 & Q0.90 & GMM \\
\hline Lagged dependent & $0.368 * * *$ & $0.565 * * *$ & $0.850 * * *$ & $0.805 * * *$ & $0.503 * * *$ & $0.190 * * *$ \\
\hline 2Lagged dependent & & & & & & -0.0811 \\
\hline$\overline{C P M}$ & $0.0353 * * *$ & 0.0155 & 0.0176 & $0.116^{* * *}$ & $0.301 * * *$ & $-0.209 * * *$ \\
\hline Capital regulation (Fitted Values) & 0.832 & $0.756^{*}$ & 0.736 & $0.817 * * *$ & $0.730 * *$ & \\
\hline Capital regulation index & & & & & & $0.914 * * *$ \\
\hline 2lagged capital regulation & & & & & & -0.831 \\
\hline Activity restrictions & $-0.234 *$ & $-0.202 *$ & $-0.299 * *$ & $-0.228 *$ & -0.419 & $-2.001 * *$ \\
\hline Deposit insurance & -0.202 & $-0.396 * * *$ & $-0.499 * * *$ & -0.330 & -0.206 & $-1.679 * *$ \\
\hline Private monitoring index & -0.137 & $-0.248 * *$ & $-0.280 * *$ & $-0.507 * * *$ & $-0.910 * * *$ & $-1.985 * * *$ \\
\hline Official supervisory power & $-0.115^{* *}$ & $-0.171 * * *$ & $-0.134 * *$ & $-0.205 * *$ & $-0.587 * * *$ & -0.210 \\
\hline Government-owned banks & $-0.0173 *$ & $-0.0307 * * *$ & $-0.0413 * * *$ & $-0.0250 *$ & $-0.0721 * *$ & $-0.451 * * *$ \\
\hline$H H I$ & $0.000341^{*}$ & $0.000308^{* *}$ & 0.000153 & $0.000413 * *$ & $0.000666^{*}$ & $0.000982 *$ \\
\hline Business freedom index & $0.140 * * *$ & $0.152 * * *$ & $0.208 * * *$ & $0.284 * * *$ & $0.522 * * *$ & $0.459 *$ \\
\hline$G D P$ & $0.126^{* * *}$ & $0.206 * * *$ & $0.186 * * *$ & $0.136^{*}$ & 0.124 & $0.255^{* *}$ \\
\hline Inflation & $-0.116^{* * *}$ & $-0.120 * *$ & -0.0720 & $-0.0844 * *$ & 0.0861 & -0.163 \\
\hline Constant & -2.572 & -16.69 & -18.07 & $-55.27 * * *$ & $-91.62 *$ & $42.01 * *$ \\
\hline Country dummy & Yes & Yes & Yes & Yes & Yes & Yes \\
\hline Time dummy & Yes & Yes & Yes & Yes & Yes & Yes \\
\hline $\begin{array}{l}\text { Observations } \\
\text { Sargan test (p-value) } \\
\text { AR(1)- (p-value })\end{array}$ & 7,991 & 7,991 & 7,991 & 7,991 & 7,991 & $\begin{array}{c}2,502 \\
0.26 \\
0.03\end{array}$ \\
\hline
\end{tabular}


CPM: Core Profitability Model; HHI: Herfindal-Hirschman Index

The dependent variable is bank stability based on CAMELS-DEA. The quantiles of fitted values are reported in columns 1 to 5 , based on instrumental variables that ethnic fractionalisation, legal origins, and independence of supervision. Bootstrapped standard errors are based on 1000 replications, though not reported here to save space. $* * *$ represents $\mathrm{p}<0.01$, $* *$ represents $\mathrm{p}<0.05$, and * represents $\mathrm{p}<0.1$ across all quantiles. GMM-two step regression is reported in columns 6 with heteroskedasticity-robust standard errors. The quantiles at Q0.10, Q0.25, Q0.50,

Q0.75 and Q0.90 are applied for Capital regulation Fitted values. $\pm \mathrm{F}$ tests for the equality of the slope coefficient across various quantiles have been undertaken and are significant at the 5\% level for most quantiles; however, they are not reported in order to save space. The details are available from the authors upon request. 
Figure 1: The distribution of explanatory variables
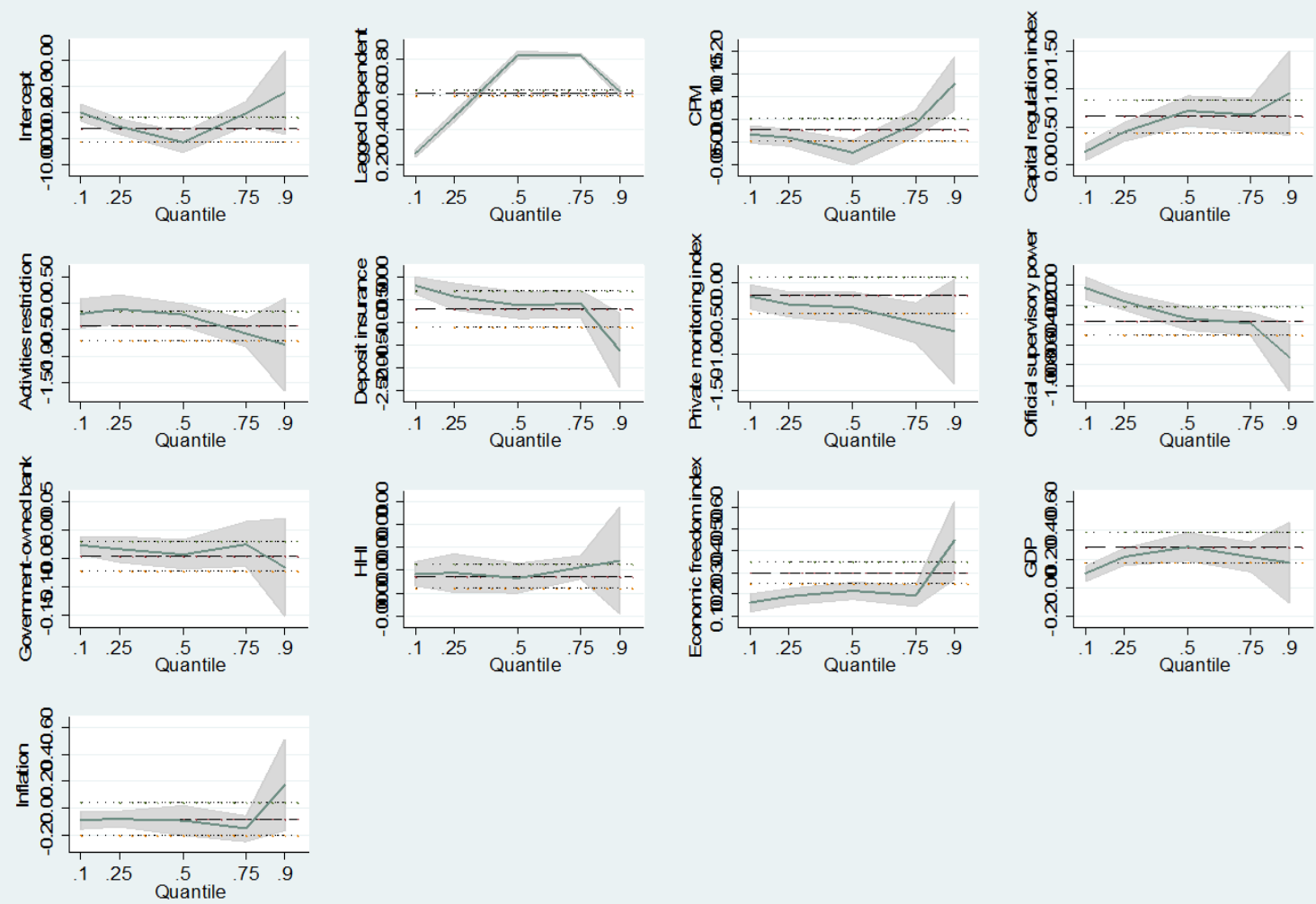

CPM: Core Profitability Model; HHI: Herfindal-Hirschman Index

The figures represent the distribution of explanatory variables at Q10, Q25, Q50, Q75, and Q90. The horizontal line represents the quantile at the 0 scale and the grey area represents a confidence band at $95 \%$ for QR. The OLS estimator is represented by the broken line. 